\title{
Ring-Size as an Independent Variable in Cyclooligomeric Depsipeptide Antiarrhythmic Activity
}

\author{
Abigail N. Smith, ${ }^{1}$ Daniel J. Blackwell, ${ }^{2}$ Bjorn C. Knollmann, ${ }^{2}$ and Jeffrey N. Johnston ${ }^{1 *}$ \\ ${ }^{1}$ Department of Chemistry and Vanderbilt Institute of Chemical Biology, Vanderbilt University, Nashville, \\ Tennessee 37235 \\ ${ }^{2}$ Vanderbilt University Medical Center Department of Medicine, Nashville, TN 37235
}

\section{Table of Contents}

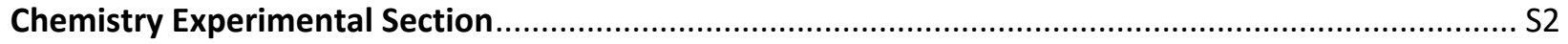

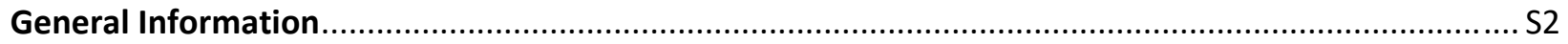

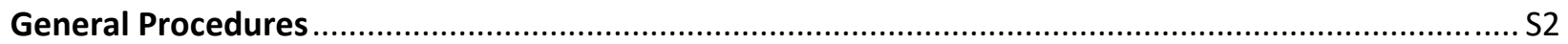

Table S1: Kinetic solubility assay summary of results in pH 7.4 phosphate buffer and Hanks Bile Salt

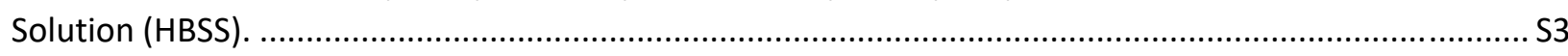

Experimental and Characterization Data for Reported Compounds.............................................. S3

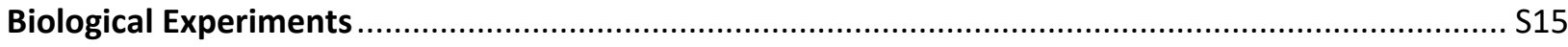

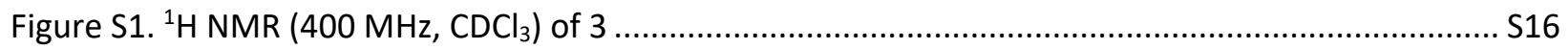

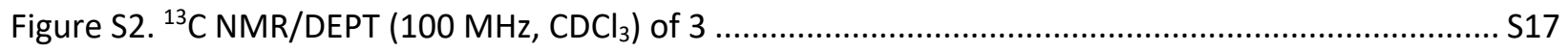

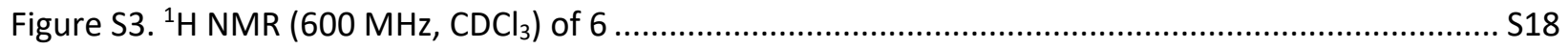

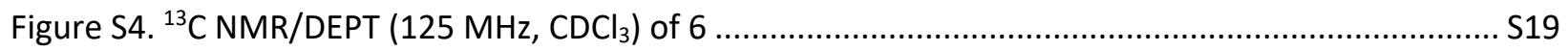

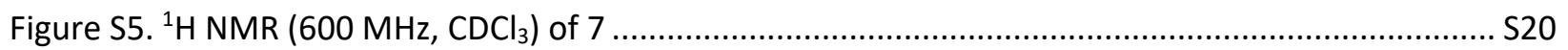

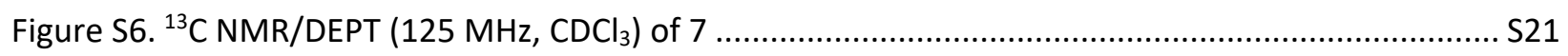

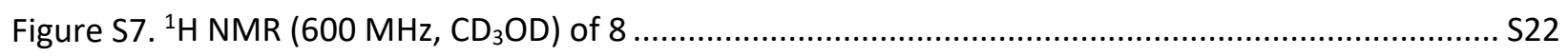

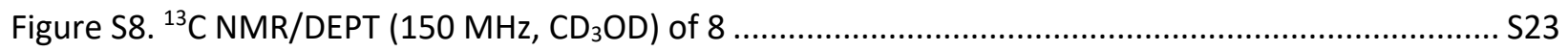

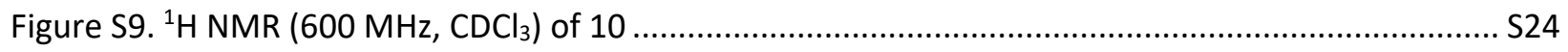

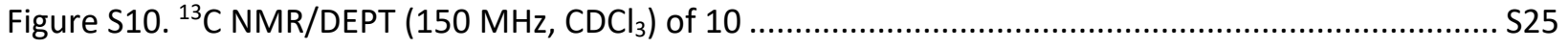

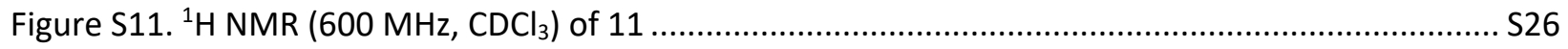

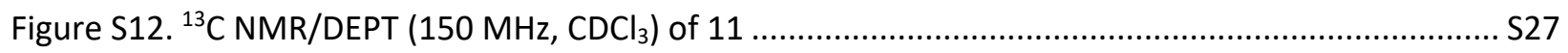

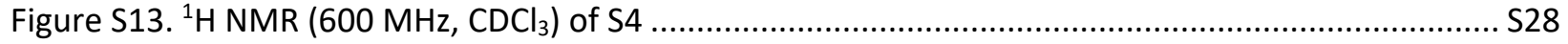

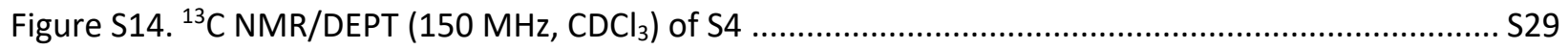

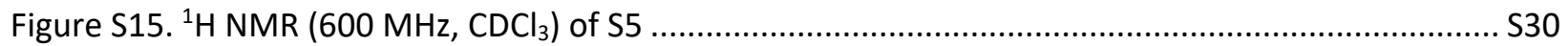

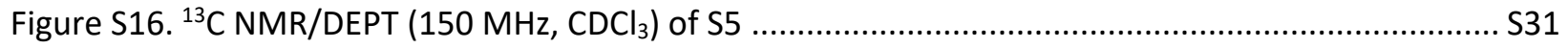




\section{Chemistry Experimental Section}

\section{General Information}

Glassware was flame-dried under vacuum for all non-aqueous reactions. All reagents and solvents were commercial grade and purified prior to use when necessary. Benzene and dichloromethane $\left(\mathrm{CH}_{2} \mathrm{Cl}_{2}\right)$ were dried by passage through a column of activated alumina as described by Grubbs. Flash column chromatography was performed using Sorbent Technologies 230-400 mesh silica gel with solvent systems indicated. Analytical thin layer column chromatography was performed using Sorbent Technologies $250 \mu \mathrm{m}$ glass backed UV254 silica gel plates and were visualized by fluorescence upon 250 $\mathrm{nm}$ radiation and/or the by use of ceric ammonium molybdate (CAM), phosphomolybdic acid (PMA), or potassium permanganate $\left(\mathrm{KMnO}_{4}\right)$. Solvent removal was affected by rotary evaporation under vacuum ( 25-40 mm Hg). All extracts were dried with $\mathrm{MgSO}_{4}$ or $\mathrm{Na}_{2} \mathrm{SO}_{4}$ unless otherwise noted. Preparative HPLC was performed on an Agilent 1260 system (column: Zorbax Eclipse XDB-C18; 21.2 mm x 150 mm, 5 $\mu \mathrm{m}$, flow rate $8 \mathrm{~mL} / \mathrm{min}$ ) with $210 \mathrm{~nm}$ monitoring wavelength and acetonitrile/water (+0.1\% TFA) gradient as indicated. Nuclear magnetic resonance spectra (NMR) were acquired on a Bruker AV-400 (400 MHz), Bruker DRX500 (500 MHz), or Bruker AV II-600 (600 MHz) instrument. Chemical shifts are measured relative to residual solvent peaks as an internal standard set to $\delta 7.26$ and $\delta 77.16\left(\mathrm{CDCl}_{3}\right)$, unless otherwise specified. Mass spectra were recorded by use of chemical ionization ( $\mathrm{Cl})$, electron impact ionization (EI), or electro-spray ionization (ESI) on a high resolution Thermo Electron Corporation MAT 95XP-Trap by the Indiana University Mass Spectrometry Facility or on a TQ-Orbitrap 3 XL Penn or Orbitrap 2 Classic FPG in the Vanderbilt Mass Spectrometry Core Laboratory. IR spectra were recorded on a Nicolet Avatar 360 spectrophotometer and are reported in wavenumbers $\left(\mathrm{cm}^{-1}\right)$ as neat films on a $\mathrm{NaCl}$ plate (transmission). Melting points were measured using an OptiMelt automated melting point system (Stanford Research Systems) and are not corrected. Chiral HPLC analysis was conducted on an Agilent 1100 series Infinity instrument using the designated ChiralPak column. Optical rotations were measured on either a Jasco P-2000 polarimeter or an AUTOPOL III (Rudolph Research Analytical) polarimeter.

Purity Statement: No in vivo work is reported. Although each final product was purified by preparative HPLC for in vitro assay, and detected by UV $(210 \mathrm{~nm})$, the compounds reported lack a good chromophore. However, the use of HPLC in combination with NMR analysis lead us to judge compounds to be a minimum of $90 \%$ pure, likely $>95 \%$. Images of NMR spectra of all new compounds are provided in the SI.

\section{General Procedures}

tert-Butyloxycarbonyl (Boc) Deprotection: A round-bottom flask was charged with the depsipeptide (1 equiv) and dissolved in $4 \mathrm{M} \mathrm{HCl}$ /dioxane (1 $\mathrm{M}$ in depsipeptide). The reaction was allowed to stir for 50 minutes at ambient temperature. The crude reaction mixture was concentrated, toluene was added, and the mixture was then reconcentrated. This procedure was repeated 3 times with toluene and 3 times with diethyl ether.

Benzyl Deprotection: A round-bottom flask was charged with the depsipeptide (1 equiv) dissolved in methanol $(0.1 \mathrm{M})$ and treated with $10 \% \mathrm{Pd} / \mathrm{C}(10 \mathrm{~mol} \%)$. The reaction flask was evacuated with a light vacuum ( 40 Torr). Hydrogen (balloon) was added and then the flask was cycled through a light vacuum three times. The reaction was stirred for $1.5 \mathrm{~h}$. The crude reaction mixture was filtered through Celite and concentrated to afford the carboxylic acid. 


\section{Kinetic Solubility Studies}

Kinetic solubility studies were performed by $\mathrm{Q}^{2}$ solutions in a $100 \mathrm{mM} \mathrm{NaPO}_{4}$ buffer (pH 7.4) and a HBSS buffer with $25 \mathrm{mM}$ Hepes. Cyclodepsipeptides were provided as a $10 \mathrm{nM}$ DMSO stock solution. Serial dilutions were performed to prepare $10,8,6,4,2$, and $1 \mathrm{mM}$ stocks. A scanning of a plate containing only buffer is done on the BMG NEPHELOStar Plus nephelometer and averaged to determine a background reading for each buffer system. Then, $2 \mu \mathrm{L}$ of DMSO stock solutions are added to $198 \mu \mathrm{L}$ of buffer and the samples are shaken for 30 seconds at $1500 \mathrm{rpm}$, resulting in the following final concentrations: 100, 80,60, 40, 20, $10 \mu \mathrm{M}$. After shaking, each sample is allowed to incubate for 2 hours at room temperature, and then each solubility plate is read using a BMG NEPHELOStar Plus nephelometer. Insolubility is determined by any well that has a reading of $>5 X$ the background reading. Solubility range is determined by measuring the first concentration out of solution and comparing to the first concentration in solution. Terfenadine and spironolactone are used as positive controls.

\begin{tabular}{|c|c|c|c|c|c|c|}
\hline & \multicolumn{2}{|c|}{ pH 7.4 phosphate buffer } & \multicolumn{3}{c|}{ Hanks Bile Salt Solution (HBSS) } \\
\hline \multirow{3}{*}{ Ring Size } & $\begin{array}{c}\text { Last } \\
\text { Soluble } \\
\text { Conc. } \\
(\mu \mathrm{M})\end{array}$ & $\begin{array}{c}\text { First } \\
\text { Soluble } \\
\text { Conc. } \\
(\mu \mathrm{M})\end{array}$ & $\begin{array}{c}\text { Solubility } \\
\text { Range }\end{array}$ & $\begin{array}{c}\text { Last } \\
\text { Soluble } \\
\text { Conc. } \\
(\mu \mathrm{M})\end{array}$ & $\begin{array}{c}\text { First } \\
\text { Soluble } \\
\text { Conc. } \\
(\mu \mathrm{M})\end{array}$ & $\begin{array}{c}\text { Solubility } \\
\text { Range }\end{array}$ \\
\hline 6 & $>100$ & & $>100$ & $>100$ & & $>100$ \\
\hline 12 & $>100$ & & $>100$ & $>100$ & & $>100$ \\
\hline 18 & $>100$ & & $>100$ & $>100$ & & $>100$ \\
\hline 24 & 21 & 40 & $21-40$ & 41 & 60 & $41-60$ \\
\hline 30 & 41 & 60 & $41-60$ & 21 & 40 & $21-40$ \\
\hline 36 & 21 & 40 & $21-40$ & 11 & 20 & $11-20$ \\
\hline
\end{tabular}

Table S1: Kinetic solubility assay summary of results in $\mathrm{pH} 7.4$ phosphate buffer and Hanks Bile Salt Solution (HBSS).

\section{Experimental and Characterization Data for Reported Compounds}

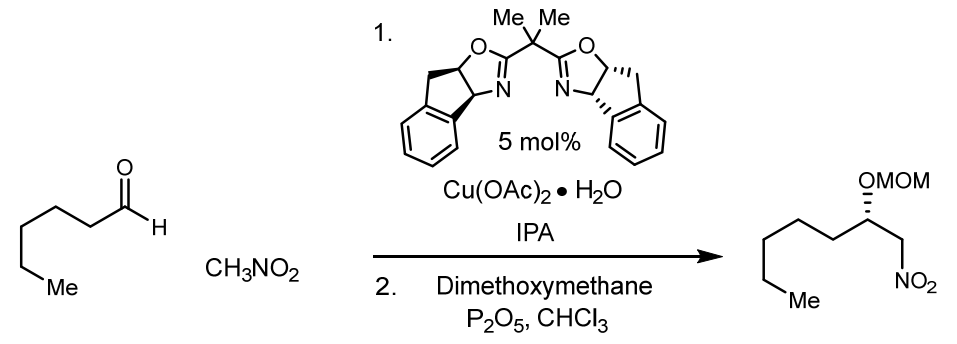

(S)-2-(Methoxymethoxy)-1-nitroheptane (2). Following the Evans protocol, ${ }^{1}$ IndaBOX (321 mg, 897

$\mu \mathrm{mol})$ and $\mathrm{Cu}(\mathrm{OAc})_{2} \bullet \mathrm{H}_{2} \mathrm{O}(162 \mathrm{mg}, 813 \mu \mathrm{mol})$ were stirred at ambient temperature in isopropanol (32.6 $\mathrm{mL}$ ) for $1 \mathrm{~h}$. The cerulean blue solution was then cooled to $0{ }^{\circ} \mathrm{C}$, and hexanal $(2.00 \mathrm{~mL}, 16.3 \mathrm{mmol})$ was

\footnotetext{
${ }^{1}$ Evans, D. A.; Seidel, D.; Rueping, M.; Lam, H. W.; Shaw, J. T.; Downey, C. W. A New Copper Acetate-Bis(oxazoline)Catalyzed, Enantioselective Henry Reaction, J. Am. Chem. Soc. 2003, 125, 12692-12693.
} 
added and allowed to stir for $10 \mathrm{~m}$ before nitromethane $(9.95 \mathrm{~mL}, 163 \mathrm{mmol})$ addition. After stirring for 4 days at ambient temperature, the reaction was quenched dropwise at $0{ }^{\circ} \mathrm{C}$ with $1 \mathrm{~N} \mathrm{HCl}$ and the aqueous layer was extracted with $\mathrm{CH}_{2} \mathrm{Cl}_{2}$. Following drying and concentration under reduced pressure, the crude alcohol was dissolved in $\mathrm{CHCl}_{3}(81.6 \mathrm{~mL})$, treated with $\mathrm{P}_{2} \mathrm{O}_{5}(23.1 \mathrm{~g}, 163 \mathrm{mmol})$ and dimethoxymethane $(33.9 \mathrm{~mL}, 326 \mathrm{mmol})$, and stirred at ambient temperature overnight. The reaction mixture was diluted with DCM and decanted from the solid. The organic layer was then washed with $\mathrm{NaHCO}_{3}$ and brine. The organic layers were dried and concentrated to afford an oil that was subjected to flash column chromatography $\left(\mathrm{SiO}_{2}, 3-6 \%\right.$ diethyl ether in hexanes) to afford the hydroxy-nitroalkane ( $2.54 \mathrm{~g}, 76 \%, 2$ steps) as a pale-yellow oil with spectroscopic data identical to its enantiomer, ${ }^{2}$ except the major/minor peaks were reversed by chiral HPLC analysis. The material was determined to be $95 \%$ ee by chiral HPLC analysis (Chiralcel OD-H, $2 \%{ }^{i} \mathrm{PrOH} /$ hexanes, $0.4 \mathrm{~mL} / \mathrm{min}, t_{\mathrm{r}}\left(e_{1}\right.$, minor) $=16.7 \mathrm{~min}, t_{\mathrm{r}}\left(e_{2}\right.$, major) $=19.1 \mathrm{~min})$.

(R)-2-(Methoxymethoxy)-1-nitroheptane (ent-2). Prepared following an identical procedure as 2. Flash column chromatography $\left(\mathrm{SiO}_{2}, 3-6 \%\right.$ ethyl acetate in hexanes) afforded the depsipeptide with spectroscopic data that matched literature. ${ }^{2}$
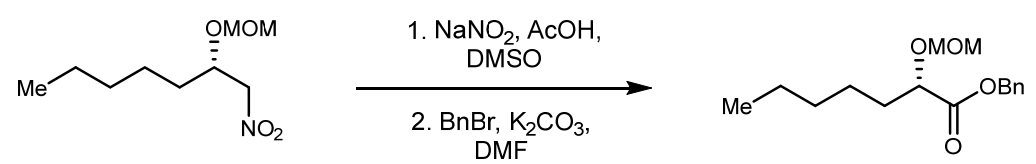

Benzyl (S)-2-(methoxymethoxy)heptanoate (3). A round-bottom flask was charged with nitroalkane (1.36 g, $6.63 \mathrm{mmol}), \mathrm{NaNO}_{2}$ (1.37 g, $\left.19.9 \mathrm{mmol}\right), \mathrm{AcOH}(5.7 \mathrm{~mL}, 99.5 \mathrm{mmol})$, and DMSO (51.0 mL). The mixture was stirred at $45^{\circ} \mathrm{C}$ for 18 hours under an argon atmosphere. The reaction was then allowed to cool to ambient temperature, treated with $1 \mathrm{~N}$ aq HCl , and poured into $\mathrm{CH}_{2} \mathrm{Cl}_{2}$. The aqueous layer was extracted with $\mathrm{CH}_{2} \mathrm{Cl}_{2}$, and the combined organic layers were washed with water, brine, dried, and concentrated. The crude mixture was then added to a round-bottom flask with $\mathrm{K}_{2} \mathrm{CO}_{3}(2.75 \mathrm{~g}, 19.9$ $\mathrm{mmol})$ and $\mathrm{DMF}(13.2 \mathrm{~mL})$. The mixture was then treated with $\mathrm{BnBr}(950 \mu \mathrm{L}, 7.95 \mathrm{mmol})$ and the reaction was allowed to stir overnight at ambient temperature under an argon atmosphere (balloon). The reaction was quenched with $1 \mathrm{~N}$ aq HCl and extracted with $\mathrm{Et}_{2} \mathrm{O}$. The organic layer was washed with $1 \mathrm{M}$ aq HCl, water, and brine, and then dried, filtered, and concentrated. The crude residue was

\footnotetext{
${ }^{2}$ Batiste, S. M.; Johnston, J. N. Rapid synthesis of cyclic oligomeric depsipeptides with positional, stereochemical, and macrocycle size distribution control, Proc. Natl. Acad. Sci. U. S. A. 2016, 113, 14893-14897.
} 
subjected to flash column chromatography $\left(\mathrm{SiO}_{2}, 5 \%\right.$ diethyl ether in hexanes) to afford the product as a pale-yellow oil (1.30 g, 70\%, 2 steps). [ $\alpha]_{D}^{20}-52.2$ (c 1.04, $\mathrm{CHCl}_{3}$ ); $\mathrm{R}_{f}=0.22$ (15\% $\mathrm{Et}_{2} \mathrm{O} /$ hexanes); IR (film) 2953, 2863, 1749, 1457, 1262, 1156, 1126, $1037 \mathrm{~cm}^{-1} ;{ }^{1} \mathrm{H}$ NMR $\left(400 \mathrm{MHz}, \mathrm{CDCl}_{3}\right) \delta$ 7.40-7.26 (m, 5H), $5.19(\mathrm{~d}, J=12.4 \mathrm{~Hz}, 1 \mathrm{H}), 5.15(\mathrm{~d}, J=12.3 \mathrm{~Hz}, 1 \mathrm{H}), 4.68(\mathrm{~d}, J=6.9 \mathrm{~Hz}, 1 \mathrm{H}), 4.65(\mathrm{~d}, J=6.9 \mathrm{~Hz}, 1 \mathrm{H}), 4.14$ (dd, $J=6.3,6.3 \mathrm{~Hz}, 1 \mathrm{H}), 3.34(\mathrm{~s}, 3 \mathrm{H}), 1.75$ (dddd, $J=7.3,7.3,7.3,7.3 \mathrm{~Hz}, 2 \mathrm{H}), 1.45-1.20(\mathrm{~m}, 6 \mathrm{H}), 0.86(\mathrm{t}, J=6.6$ $\mathrm{Hz}, 3 \mathrm{H}) ;{ }^{13} \mathrm{C} \mathrm{NMR}\left(100 \mathrm{MHz}, \mathrm{CDCl}_{3}\right)$ ppm 172.7, 135.7, 128.6, 128.4, 128.3, 96.3, 75.7, 66.5, 56.0, 32.9, 31.5, 24.9, 22.5, 14.0; HRMS (EI): Exact mass calcd for $\mathrm{C}_{16} \mathrm{H}_{24} \mathrm{O}_{4} \mathrm{Na}[\mathrm{M}+\mathrm{Na}]^{+} 303.1567$, found 303.1569.

Benzyl (R)-2-(methoxymethoxy)heptanoate (ent-3) Prepared following an identical procedure as 3. Flash column chromatography $\left(\mathrm{SiO}_{2}, 5 \%\right.$ ethyl acetate in hexanes) afforded the depsipeptide with spectroscopic data identical to its enantiomer, except $[\alpha]_{D}^{23}+52\left(c 0.90, \mathrm{CHCl}_{3}\right)$.

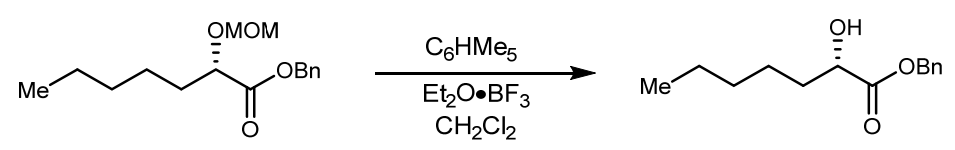

Benzyl (S)-2-hydroxyheptanoate (4). A flame-dried round-bottom flask was charged with the protected alcohol (2.15 g, $7.67 \mathrm{mmol})$ dissolved in dry dichloromethane (0.05 M), pentamethyl benzene (3.4 mg, $23.0 \mathrm{mmol})$, and $\mathrm{BF}_{3} \cdot \mathrm{Et}_{2} \mathrm{O}(2.84 \mathrm{~mL}, 23.0 \mathrm{mmol})$. The reaction was allowed to stir for 50 minutes at ambient temperature. The crude reaction mixture was quenched with satd aq $\mathrm{NaHCO}_{3}$, washed with brine, dried, concentrated, and subjected to flash column chromatography $\left(\mathrm{SiO}_{2}, 10-30 \%\right.$ ethyl acetate in hexanes) to afford the alcohol $(1.20 \mathrm{mg}, 67 \%)$ as a yellow oil. All spectral data are in agreement with literature values ${ }^{3}$ reported for the enantiomer except $[\alpha]_{D}^{23}+17$ (c. $0.90, \mathrm{CHCl}_{3}$ ).

Benzyl (R)-2-hydroxyheptanoate (ent-4). Prepared following an identical procedure as 4 . Flash column chromatography $\left(\mathrm{SiO}_{2}, 10-30 \%\right.$ ethyl acetate in hexanes) afforded the depsipeptide. All spectral data are in agreement with literature values. ${ }^{3}$

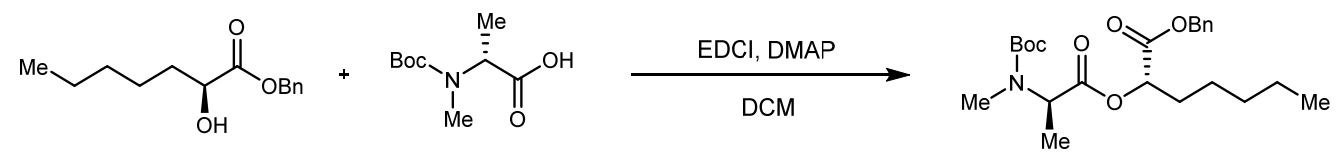

Benzyl (S)-2-((N-(tert-butoxycarbonyl)-N-methyl-D-alanyl)oxy)heptanoate (5). A round-bottom flask was charged with the amine (1.19 g, $5.84 \mathrm{mmol})$, alcohol $(1.20 \mathrm{~g}, 5.08 \mathrm{mmol})$, and DCM $(51 \mathrm{~mL})$. The mixture was cooled to $0{ }^{\circ} \mathrm{C}$ and then $\operatorname{EDCl}(1.17 \mathrm{~g}, 6.09 \mathrm{mmol})$ and DMAP $(31.0 \mathrm{mg}, 254 \mu \mathrm{mol})$ were

\footnotetext{
${ }^{3}$ Monma, S.; Sunazuka, T.; Nagai, K.; Arai, T.; Shiomi, K.; Matsui, R.; Ōmura, S. Verticilide: Elucidation of Absolute Configuration and Total Synthesis, Organic Letters 2006, 8, 5601-5604.
} 
added. The reaction was stirred at $0{ }^{\circ} \mathrm{C}$ for $30 \mathrm{~min}$, then allowed to warm to ambient temperature and stir for an additional $1.5 \mathrm{~h}$. The reaction mixture was poured into water and extracted with DCM. The combined organic layers were washed with $\mathrm{NaHCO}_{3}$ and brine, and then dried, filtered, and concentrated. The crude residue was subjected to flash column chromatography $\left(\mathrm{SiO}_{2}, 10 \%\right.$ ethyl acetate in hexanes) to afford the product as a colorless oil $(1.88 \mathrm{~g}, 88 \%)$. All spectral data are in agreement with literature values ${ }^{3}$ reported for the enantiomer, except $[\alpha]_{D}^{26}+12\left(c 0.94, \mathrm{CHCl}_{3}\right)$.

\section{Benzyl (R)-2-((N-(tert-butoxycarbonyl)-N-methyl-L-alanyl)oxy)heptanoate (ent-5). Prepared following} an identical procedure as 5 . Flash column chromatography $\left(\mathrm{SiO}_{2}, 10 \%\right.$ ethyl acetate in hexanes) afforded the depsipeptide. All spectral data are in agreement with literature values. ${ }^{3}$
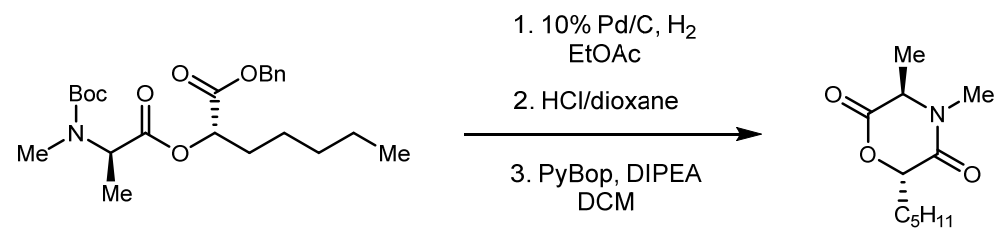

(3R,6S)-3,4-Dimethyl-6-pentylmorpholine-2,5-dione (6). A round-bottom flask was charged with the depsipeptide $(24.0 \mathrm{mg}, 56.9 \mu \mathrm{mol})$, dissolved in EtOAc $(2.0 \mathrm{~mL})$, and treated with $10 \% \mathrm{Pd} / \mathrm{C}(3.0 \mathrm{mg})$. The reaction flask was evacuated with light vacuum (50 Torr). A hydrogen (balloon) was added, and the cycle was repeated once more. The reaction mixture was stirred for $1 \mathrm{~h}$. After purging the flask with nitrogen, the crude reaction mixture was filtered through Celite. To the crude material was added $\mathrm{HCl}$ in dioxane $(5 \mathrm{~mL})$, and the reaction mixture was allowed to stir for $30 \mathrm{~min}$. The reaction mixture was concentrated and transferred to a flame-dried round bottom flask. DMF $(11.3 \mathrm{~mL})$ was added and the reaction was cooled to $0{ }^{\circ} \mathrm{C}$. DIPEA $(21.4 \mu \mathrm{L}, 125 \mu \mathrm{mol})$ and PyBop $(32.4 \mathrm{mg}, 62.4 \mu \mathrm{mol})$ were added. The reaction was stirred at $0{ }^{\circ} \mathrm{C}$ for $30 \mathrm{~min}$, then allowed to warm to ambient temperature and stir for an additional $2 \mathrm{~h}$. The reaction mixture was poured into cold $10 \%$ aq citric acid and extracted with DCM. The combined organic layers were washed with $\mathrm{NaHCO}_{3}$ and brine, and then dried, filtered, and concentrated. Preparative HPLC ( $5-95 \%$ aqueous acetonitrile, $210 \mathrm{~nm}$, flow rate: $8 \mathrm{~mL} / \mathrm{min}, \mathrm{R}_{\mathrm{t}}=15.6 \mathrm{~m}$ ) afforded the 6-membered ring (11.3 mg, 94\%) as a colorless oil. $[\alpha]_{D}^{25}-110$ (c $\left.0.48, \mathrm{CHCl}_{3}\right) ; \mathrm{R}_{f}=0.33$ (4\% MeOH/DCM);

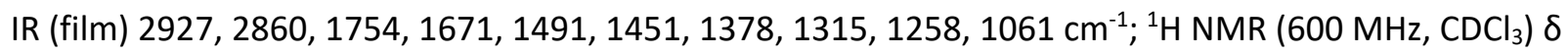
$4.78(\mathrm{dd}, J=7.4,3.8 \mathrm{~Hz}, 1 \mathrm{H}), 4.13(\mathrm{q}, J=7.3 \mathrm{~Hz}, 1 \mathrm{H}$ ), $2.98(\mathrm{~s}, 3 \mathrm{H}), 2.10$ (dddd, $J=14.5,10.8,5.7,3.8 \mathrm{~Hz}$, 1H), 1.92 (dddd, $J=14.5,10.6,7.5,4.7 \mathrm{~Hz}, 1 \mathrm{H}$ ), 1.56 (d, $J=7.3 \mathrm{~Hz}, 3 \mathrm{H}$ ), 1.53-1.40 (series of $\mathrm{m}, 2 \mathrm{H}$ ), 1.37$1.28(\mathrm{~m}, 4 \mathrm{H}), 0.89(\mathrm{t}, J=7.1 \mathrm{~Hz}, 3 \mathrm{H}) ;{ }^{13} \mathrm{C}$ NMR $\left(150 \mathrm{MHz}, \mathrm{CDCl}_{3}\right) \mathrm{ppm}$ 168.1, 165.7, 77.7, 56.9, 32.0, 31.5, 31.3, 24.3, 22.6, 16.8, 14.1; HRMS (EI): Exact mass calcd for $\mathrm{C}_{11} \mathrm{H}_{19} \mathrm{NO}_{3}[\mathrm{M}]^{+} 213.1365$, found 213.1361. 
(3S,6R)-3,4-Dimethyl-6-pentylmorpholine-2,5-dione (ent-6). Prepared following an identical procedure as 6. Preparative HPLC ( $5-95 \%$ aqueous acetonitrile, $210 \mathrm{~nm}$, flow rate: $\left.8 \mathrm{~mL} / \mathrm{min}, \mathrm{R}_{\mathrm{t}}=15.6 \mathrm{~m}\right)$ afforded the 6-membered ring with spectroscopic data identical to its enantiomer, except $[\alpha]_{D}^{23}+109$ (c 0.57 , $\left.\mathrm{CHCl}_{3}\right)$.

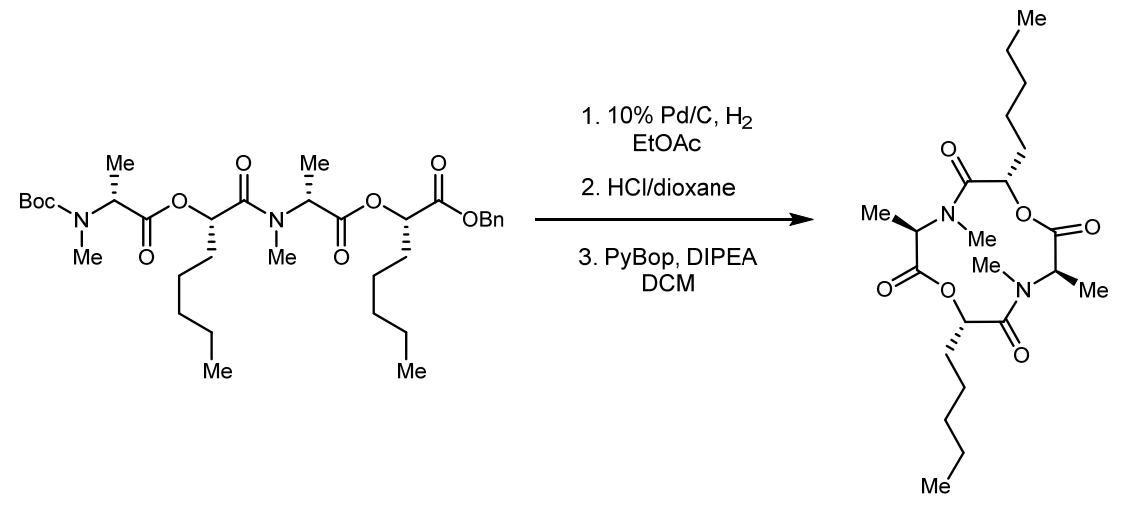

(3S,6R,9S,12R)-3,4,9,10-Tetramethyl-6,12-dipentyl-1,7-dioxa-4,10-diazacyclododecane-2,5,8,11-

tetraone (7). A round-bottom flask was charged with the depsipeptide $(62.2 \mathrm{mg}, 98.0 \mu \mathrm{mol})$, dissolved in EtOAc $(5.0 \mathrm{~mL})$, and treated with $10 \% \mathrm{Pd} / \mathrm{C}(7 \mathrm{mg})$. The reaction flask was evacuated with light vacuum (50 Torr). Hydrogen (balloon) was added, and the cycle was repeated once more. The reaction was stirred for $1 \mathrm{~h}$. After purging the flask with nitrogen, the crude reaction mixture was filtered through Celite. To the crude material was added $\mathrm{HCl}$ in dioxane $(5 \mathrm{~mL})$ and the reaction mixture was allowed to stir for $30 \mathrm{~min}$. The reaction mixture was concentrated and transferred to a flame-dried round bottom flask. DMF $(20.6 \mathrm{~mL})$ was added and the reaction was cooled to $0{ }^{\circ} \mathrm{C}$. DIPEA (38.8 $\left.\mu \mathrm{L}, 22.7 \mu \mathrm{mol}\right)$ and PyBop (58.8 mg, $113 \mu \mathrm{mol}$ ) were added. The reaction was stirred at $0{ }^{\circ} \mathrm{C}$ for $30 \mathrm{~min}$, then allowed to warm to ambient temperature and stir for an additional $2 \mathrm{~h}$. The reaction mixture was poured into cold $10 \%$ aq citric acid and extracted with DCM. The combined organic layers were washed with $\mathrm{NaHCO}_{3}$, brine, dried, and concentrated. Preparative HPLC (5 - 95\% aqueous acetonitrile, $210 \mathrm{~nm}$, flow rate: 8 $\left.\mathrm{mL} / \mathrm{min}, \mathrm{R}_{\mathrm{t}}=19.1 \mathrm{~m}\right)$ afforded the 6-membered ring $(9.0 \mathrm{mg}, 21 \%)$ as a white amorphous solid. $[\alpha]_{D}^{25}+$ 21 (c 0.50, $\mathrm{CHCl}_{3}$ ); $\mathrm{R}_{f}=0.37$ (4\% MeOH/DCM); IR (film) 2954, 2929, 2859, 1749, 1649, 1488, 1456, 1434, $1379,1314,1260,1149,1086 \mathrm{~cm}^{-1}$; ${ }^{1} \mathrm{H}$ NMR $\left(600 \mathrm{MHz}, \mathrm{CDCl}_{3}\right)$ This compound exists in multiple conformations. There is a clear major conformation (see spectra) and the line listing for that conformation is: $\delta 5.17(\mathrm{dd}, J=9.1,5.7 \mathrm{~Hz}, 2 \mathrm{H}), 4.88(\mathrm{q}, J=7.2 \mathrm{~Hz}, 2 \mathrm{H}), 2.99(\mathrm{~s}, 6 \mathrm{H}), 1.93-1.77(\mathrm{~m}, 4 \mathrm{H})$, $1.48(\mathrm{~d}, J=7.2 \mathrm{~Hz}, 6 \mathrm{H}), 1.61-1.28$ (series of $\mathrm{m}, 12 \mathrm{H}), 0.90(\mathrm{t}, J=7.1 \mathrm{~Hz}, 6 \mathrm{H}) ;{ }^{13} \mathrm{C} \mathrm{NMR}\left(150 \mathrm{MHz}, \mathrm{CDCl}_{3}\right)$ ppm 170.6, 169.3, 78.4, 53.6, 32.0, 31.3, 29.7, 25.5, 22.5, 16.1, 14.1; HRMS (El): Exact mass calcd for $\mathrm{C}_{22} \mathrm{H}_{38} \mathrm{~N}_{2} \mathrm{NaO}_{6}[\mathrm{M}+\mathrm{Na}]^{+} 449.2622$, found 449.2623. 

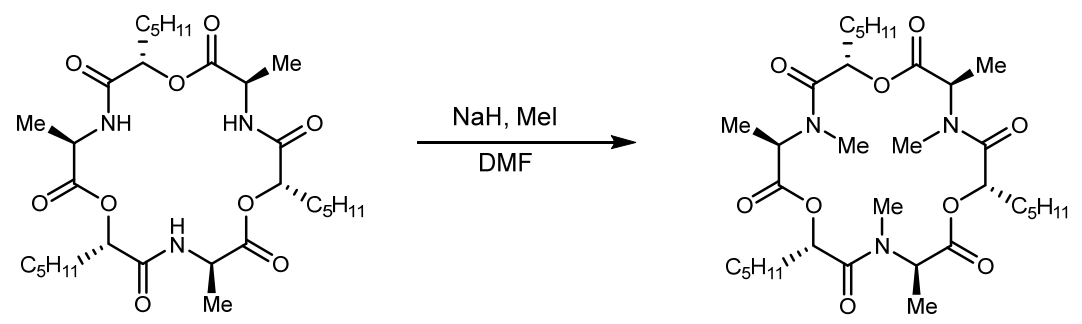

(3R,6S,9R,12S,15R,18S)-3,9,15-Trimethyl-6,12,18-tripentyl-1,7,13-trioxa-4,10,16-

triazacyclooctadecane-2,5,8,11,14,17-hexaone (8). A flame-dried round-bottom flask was charged with $\mathrm{N}-\mathrm{H}$ cyclic depsipeptide $(16.7 \mathrm{mg}, 27.9 \mu \mathrm{mol})$ and dry DMF $(558 \mu \mathrm{L})$ at $0{ }^{\circ} \mathrm{C}$. Methyl iodide $(70 \mu \mathrm{L}, 1.12$ $\mathrm{mmol})$ was then added to the reaction mixture, and $\mathrm{NaH}(6.7 \mathrm{mg}, 279 \mu \mathrm{mol}$ in DMF $(279 \mu \mathrm{L}))$ was added slowly, in $56 \mu \mathrm{L}$ aliquots over 15 minutes. The reaction was allowed to stir at $0{ }^{\circ} \mathrm{C}$ for $25 \mathrm{~m}$, and it was then quenched by the dropwise addition of satd aq $\mathrm{NH}_{4} \mathrm{Cl}$. The aqueous layer was extracted with EtOAc, and the combined organic layers were washed with satd aq $\mathrm{NaHCO}_{3}$, satd aq $\mathrm{Na}_{2} \mathrm{~S}_{2} \mathrm{O}_{3}$, water, and brine. The organic layer was then dried and concentrated to afford a colorless oil. Preparative HPLC (55 - 95\% aqueous acetonitrile, $210 \mathrm{~nm}$, flow rate: $8 \mathrm{~mL} / \mathrm{min}, \mathrm{R}_{\mathrm{t}}=28.7 \mathrm{~m}$ ) afforded the 18-membered macrocycle (7.5 mg, 42\%). $[\alpha]_{D}^{20}+7.5$ (c 0.40, $\mathrm{CHCl}_{3}$ ); $\mathrm{R}_{f}=0.67$ (10\% MeOH/DCM); IR (film) 2924, 2855, 1746, 1665, 1462, 1199, $1100 \mathrm{~cm}^{-1} ;{ }^{1} \mathrm{H}$ NMR (600 MHz, CD $\left.{ }_{3} \mathrm{OD}\right) \delta 5.35$ (dd, $\left.J=8.8,4.6 \mathrm{~Hz}, 1 \mathrm{H}\right), 5.00(\mathrm{q}, J=7.5 \mathrm{~Hz}, 1 \mathrm{H})$, $3.09(\mathrm{~s}, 3 \mathrm{H}), 1.84-1.76(\mathrm{~m}, 2 \mathrm{H}), 1.45(\mathrm{~d}, J=7.6 \mathrm{~Hz}, 3 \mathrm{H}), 1.39-1.29(\mathrm{~m}, 6 \mathrm{H}), 0.93(\mathrm{t}, J=6.8 \mathrm{~Hz}, 3 \mathrm{H}) ;{ }^{13} \mathrm{C}$ NMR (150 MHz, CD $\left.{ }_{3} \mathrm{OD}\right)$ ppm 172.9, 172.4, 72.8, 53.7, 32.5, 31.9, 31.3, 26.2, 23.6, 14.5, 14.3; HRMS (EI): Exact mass calcd for $\mathrm{C}_{33} \mathrm{H}_{57} \mathrm{~N}_{3} \mathrm{NaO}_{9}[\mathrm{M}+\mathrm{Na}]^{+} 662.3987$, found 662.4021 .

\section{(3S,6R,9S,12R,15S,18R)-3,9,15-Trimethyl-6,12,18-tripentyl-1,7,13-trioxa-4,10,16-}

triazacyclooctadecane-2,5,8,11,14,17-hexaone (ent-8). Prepared following an identical procedure as 8.

Preparative HPLC (55 - 95\% aqueous acetonitrile, $210 \mathrm{~nm}$, flow rate: $8 \mathrm{~mL} / \mathrm{min}, R_{t}=28.7 \mathrm{~m}$ ) afforded the 18-membered macrocycle with spectroscopic data identical to its enantiomer, except $[\alpha]_{D}^{25}-7.2$ (c 0.59 , $\left.\mathrm{CHCl}_{3}\right)$.

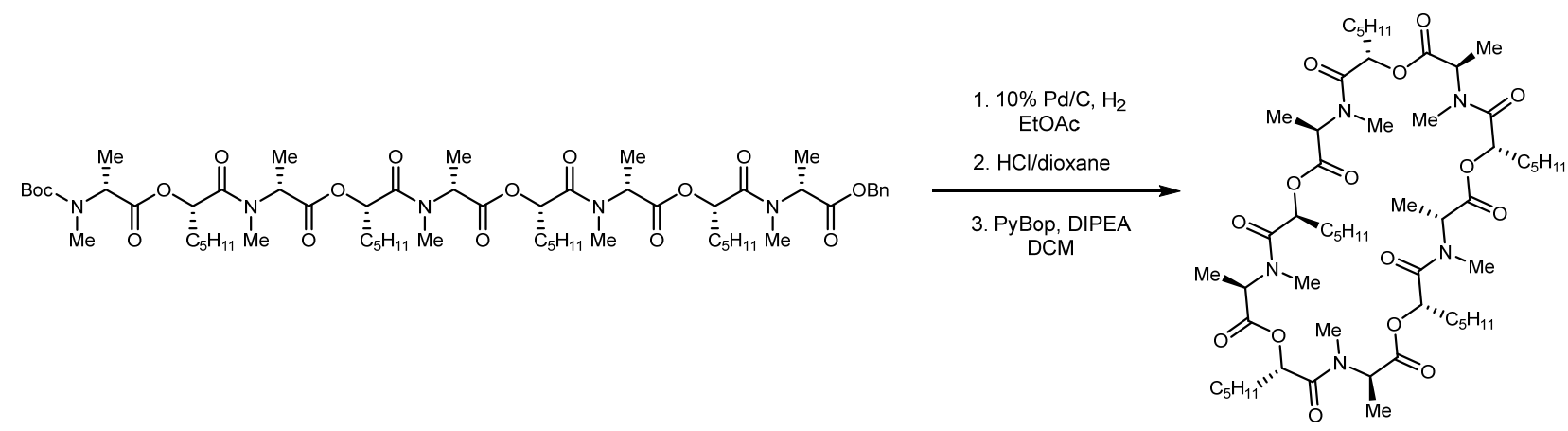


$(3 R, 6 S, 9 R, 12 S, 15 R, 18 S, 21 R, 24 S, 27 R, 30 S)-3,4,9,10,15,16,21,22,27,28-D e c a m e t h y l-6,12,18,24,30-$ pentapentyl-1,7,13,19,25-pentaoxa-4,10,16,22,28-pentaazacyclotriacontane

$\mathbf{2 , 5}, \mathbf{8}, \mathbf{1 1}, \mathbf{1 4}, \mathbf{1 7}, \mathbf{2 0}, \mathbf{2 3}, \mathbf{2 6}, \mathbf{2 9}$-decaone (10). A round-bottom flask was charged with the depsipeptide $(50.0 \mathrm{mg}, 39.3 \mu \mathrm{mol})$, dissolved in EtOAc $(0.3 \mathrm{~mL})$, and treated with $10 \% \mathrm{Pd} / \mathrm{C}(1.0 \mathrm{mg})$. The reaction flask was evacuated with light vacuum (50 Torr). Hydrogen (balloon) was added, and the cycle was repeated once more. The reaction was stirred for $1 \mathrm{~h}$. After purging the flask with nitrogen, the crude reaction mixture was filtered through Celite. To the crude material was added $\mathrm{HCl}$ in dioxane $(0.4 \mathrm{~mL})$ and the reaction mixture was allowed to stir for $30 \mathrm{~min}$. The reaction mixture was concentrated and added to a flame-dried round bottom flask. DCM $(7.8 \mathrm{~mL})$ was added and the reaction was cooled to 0 ${ }^{\circ} \mathrm{C}$. DIPEA (15 $\left.\mu \mathrm{L}, 86 \mu \mathrm{mol}\right)$ and PyBop $(21.4 \mathrm{mg}, 41.2 \mu \mathrm{mol})$ were added. The reaction was stirred at $0{ }^{\circ} \mathrm{C}$ for $30 \mathrm{~min}$, then allowed to warm to ambient temperature and stirred for an additional $1.5 \mathrm{~h}$. The reaction mixture was poured into cold $10 \%$ aq citric acid and extracted with DCM. The combined organic layers were washed with $\mathrm{NaHCO}_{3}$ and brine, and dried, filtered, and concentrated. Preparative HPLC (5 $95 \%$ aqueous acetonitrile, $210 \mathrm{~nm}$, flow rate: $8 \mathrm{~mL} / \mathrm{min}, R_{t}=25-28 \mathrm{~m}$ ) afforded the 30 -membered macrocycle (12.3 mg, 30\%) as a colorless oil. $[\alpha]_{D}^{20}+40\left(c 0.62, \mathrm{CHCl}_{3}\right) ; \mathrm{R}_{f}=0.34(4 \% \mathrm{MeOH} / \mathrm{DCM}) ; \mathrm{IR}$ (film) 2930, 2861, 1743, 1653, 1462, 1204, $1093 \mathrm{~cm}^{-1} ;{ }^{1} \mathrm{H} \mathrm{NMR}\left(600 \mathrm{MHz}, \mathrm{CDCl}_{3}\right)$ This compound exists in multiple conformations, causing significant peak overlap. Refer to the image of the ${ }^{1} \mathrm{H}$ NMR spectrum; ${ }^{13} \mathrm{C} \mathrm{NMR}\left(150 \mathrm{MHz}, \mathrm{CDCl}_{3}\right.$ ) This compound exists in multiple conformations, causing significant peak overlap. Refer to image of the ${ }^{13} \mathrm{C}$ NMR spectrum; HRMS (EI): Exact mass calcd for $\mathrm{C}_{55} \mathrm{H}_{96} \mathrm{~N}_{5} \mathrm{O}_{15}[\mathrm{M}+\mathrm{H}]^{+}$ 1066.6897, found 1066.6889 .

$(3 S, 6 R, 9 S, 12 R, 15 S, 18 R, 21 S, 24 R, 27 S, 30 R)-3,4,9,10,15,16,21,22,27,28-D e c a m e t h y l-6,12,18,24,30-$ pentapentyl-1,7,13,19,25-pentaoxa-4,10,16,22,28-pentaazacyclotriacontane $\mathbf{2 , 5 , 8 , 1 1 , 1 4 , 1 7 , 2 0 , 2 3 , 2 6 , 2 9 - d e c a o n e ~ ( e n t - 1 0 ) . ~ P r e p a r e d ~ f o l l o w i n g ~ a n ~ i d e n t i c a l ~ p r o c e d u r e ~ a s ~} 10$. Preparative HPLC ( 5 - 95\% aqueous acetonitrile, $210 \mathrm{~nm}$, flow rate: $8 \mathrm{~mL} / \mathrm{min}, \mathrm{R}_{\mathrm{t}}=25-28 \mathrm{~m}$ ) afforded the 30-membered macrocycle with spectroscopic data identical to its enantiomer, except $[\alpha]_{D}^{20}-33$ (c $\left.0.68, \mathrm{CHCl}_{3}\right)$. 


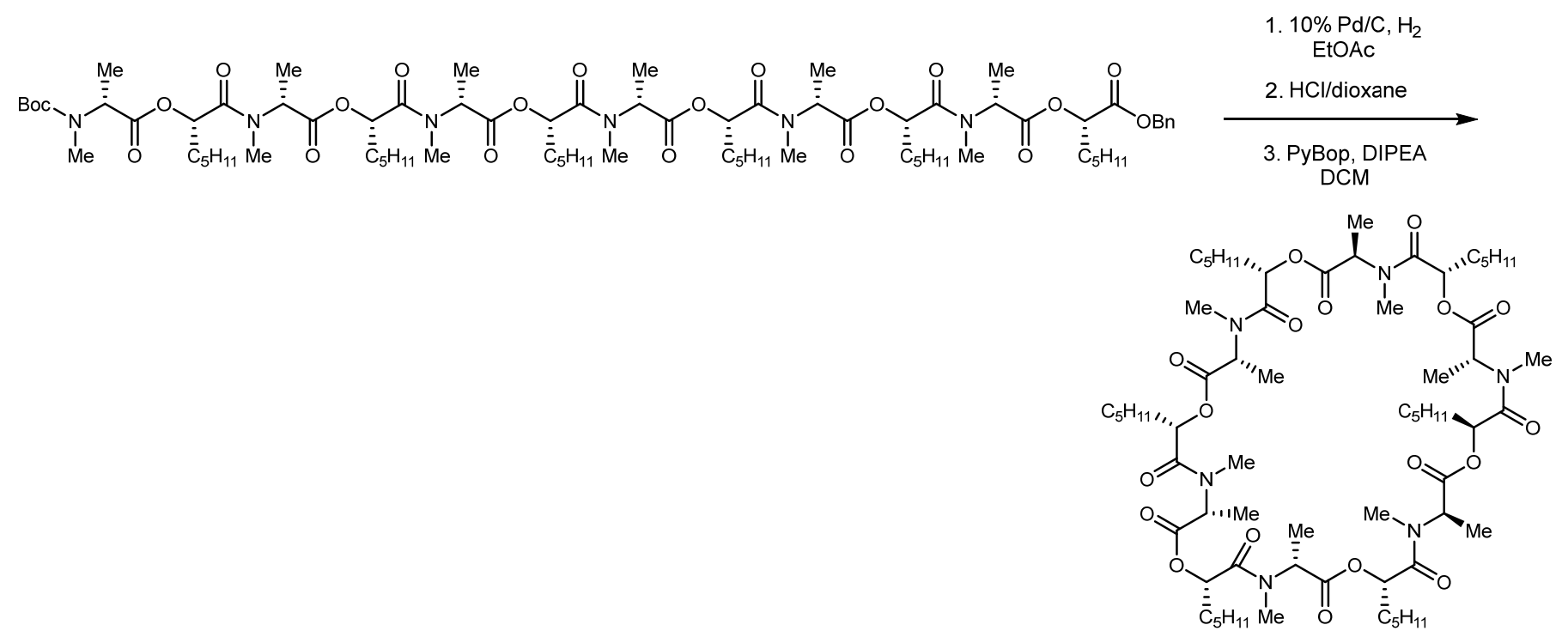

$(3 R, 6 S, 9 R, 12 S, 15 R, 18 S, 21 R, 24 S, 27 R, 30 S, 33 R, 36 S)-3,4,9,10,15,16,21,22,27,28,33,34$-Dodecamethyl6,12,18,24,30,36-hexapentyl-1,7,13,19,25,31-hexaoxa-4,10,16,22,28,34-hexaazacyclohexatriacontane2,5,8,11,14,17,20,23,26,29,32,35-dodecaone (11). A round-bottom flask was charged with the depsipeptide (70 mg, $47 \mu \mathrm{mol})$, dissolved in EtOAc $(0.3 \mathrm{~mL})$, and treated with $10 \% \mathrm{Pd} / \mathrm{C}(1.0 \mathrm{mg})$. The reaction flask was evacuated with light vacuum (50 Torr). Hydrogen (balloon) was added, and the cycle was repeated once more. The reaction was stirred for $1 \mathrm{~h}$. After purging the flask with nitrogen, the crude reaction mixture was filtered through Celite. To the crude material was added $\mathrm{HCl}$ in dioxane $(0.3$ $\mathrm{mL}$ ) and the reaction mixture was allowed to stir for $30 \mathrm{~min}$. The reaction mixture was concentrated and transferred to a flame-dried round bottom flask. DCM $(8.2 \mathrm{~mL})$ was added and the reaction was cooled to $0{ }^{\circ} \mathrm{C}$. DIPEA $(15.3 \mu \mathrm{L}, 89.3 \mu \mathrm{mol})$ and PyBop $(22.4 \mathrm{mg}, 43.1 \mu \mathrm{mol})$ were added. The reaction was stirred at $0{ }^{\circ} \mathrm{C}$ for $30 \mathrm{~min}$, then allowed to warm to ambient temperature and stir for an additional $1.5 \mathrm{~h}$. The reaction mixture was poured into cold $10 \%$ aq citric acid and extracted with DCM. The combined organic layers were washed with $\mathrm{NaHCO}_{3}$ and brine, and then dried, filtered, and concentrated. Preparative HPLC ( $5-95 \%$ aqueous acetonitrile, $210 \mathrm{~nm}$, flow rate: $8 \mathrm{~mL} / \mathrm{min}, \mathrm{R}_{\mathrm{t}}=30-32 \mathrm{~m}$ ) afforded the 36-membered macrocycle (30 mg, 55\%) as a colorless oil. $[\alpha]_{D}^{25}+33\left(c 0.46, \mathrm{CHCl}_{3}\right) ; \mathrm{R}_{f}=0.22(4 \%$ MeOH/DCM); IR (film) 2932, 2864, 1743, 1660, 1461, 1212, $1102 \mathrm{~cm}^{-1} ;{ }^{1} \mathrm{H}$ NMR (400 MHz, CDCl $)$ This compound exists in multiple conformations, causing significant peak overlap. Refer to the image of the ${ }^{1} \mathrm{H}$ NMR spectrum; ${ }^{13} \mathrm{C}$ NMR $\left(150 \mathrm{MHz}, \mathrm{CDCl}_{3}\right)$ This compound exists in multiple conformations, causing significant peak overlap. Refer to image of the ${ }^{13} \mathrm{C}$ NMR spectrum; HRMS (EI): Exact mass calcd for $\mathrm{C}_{66} \mathrm{H}_{115} \mathrm{~N}_{6} \mathrm{O}_{18}[\mathrm{M}+\mathrm{H}]^{+}$1279.8262, found 1279.8259 . 
$(3 S, 6 R, 9 S, 12 R, 15 S, 18 R, 21 S, 24 R, 27 S, 30 R, 33 S, 36 R)-3,4,9,10,15,16,21,22,27,28,33,34-D o d e c a m e t h y l-$ 6,12,18,24,30,36-hexapentyl-1,7,13,19,25,31-hexaoxa-4,10,16,22,28,34-hexaazacyclohexatriacontane2,5,8,11,14,17,20,23,26,29,32,35-dodecaone (ent-11). Prepared following an identical procedure as 11. Preparative HPLC ( $5-95 \%$ aqueous acetonitrile, $210 \mathrm{~nm}$, flow rate: $8 \mathrm{~mL} / \mathrm{min}, \mathrm{R}_{\mathrm{t}}=30-32 \mathrm{~m}$ ) afforded the 36-membered macrocycle with spectroscopic data identical to its enantiomer, except $[\alpha]_{D}^{20}-36$ (c $\left.0.51, \mathrm{CHCl}_{3}\right)$.

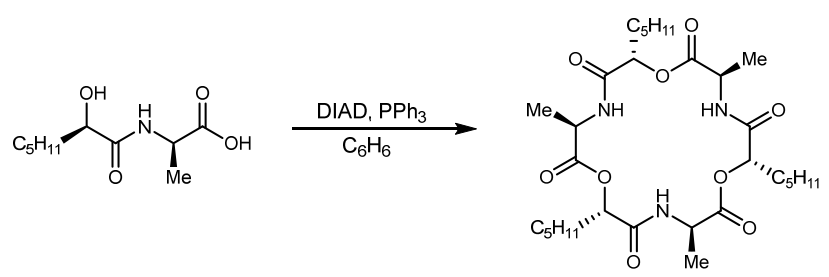

\section{(3R,6S,9R,12S,15R,18S)-3,9,15-trimethyl-6,12,18-tripentyl-1,7,13-trioxa-4,10,16-}

triazacyclooctadecane-2,5,8,11,14,17-hexaone (S1). The 18-membered ring was prepared following our previously reported MCO protocol. ${ }^{4}$ Purification afforded the 18 -membered macrocycle $(6.0 \mathrm{mg}, 62 \%)$ as an amorphous white solid. All spectral data are in agreement with literature values. ${ }^{4}$
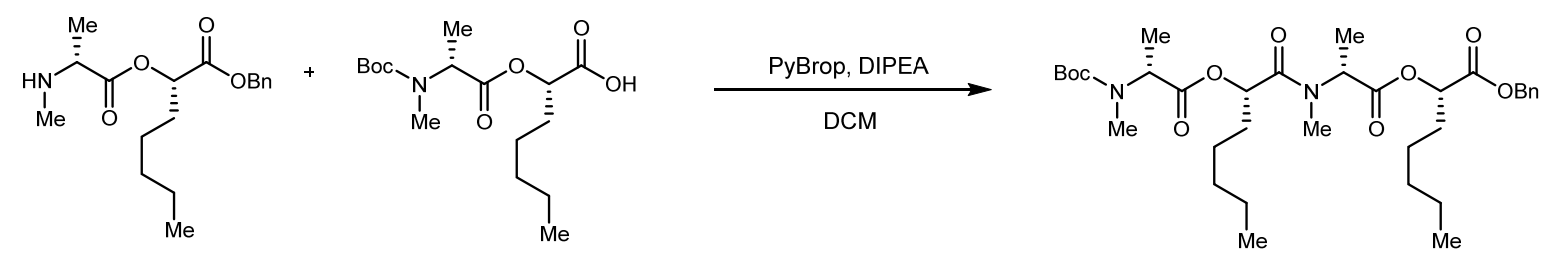

\section{Benzyl (S)-2-(((6R,9S,12R)-2,2,5,6,11,12-hexamethyl-4,7,10-trioxo-9-pentyl-3,8-dioxa-5,11-}

diazatridecan-13-oyl)oxy)heptanoate (S2). A round-bottom flask was charged with the amine (231 mg, $717 \mu \mathrm{mol})$, acid $(236 \mathrm{mg}, 717 \mu \mathrm{mol})$, and DCM $(4.0 \mathrm{~mL})$. The mixture was cooled to $0{ }^{\circ} \mathrm{C}$ and then DIPEA $\left(370 \mu \mathrm{L}, 2.15 \mathrm{mmol}\right.$ ) and PyBrop (502 mg, $1.08 \mathrm{mmol}$ ) were added. The reaction was stirred at $0{ }^{\circ} \mathrm{C}$ for 1 h. The reaction mixture was poured into cold $10 \%$ aq citric acid and extracted with DCM. The combined organic layers were washed with $\mathrm{NaHCO}_{3}$ and brine, and then dried, filtered, and concentrated. The crude residue was subjected to flash column chromatography $\left(\mathrm{SiO}_{2}, 10-40 \%\right.$ ethyl acetate in hexanes) to afford the product as a colorless oil (330 mg, 73\%). All spectral data are in agreement with literature values $^{3}$ reported for the enantiomer, except $[\alpha]_{D}^{26}+28.0\left(c 1.00, \mathrm{CHCl}_{3}\right)$.

\footnotetext{
${ }^{4}$ Smith, A. N.; Johnston, J. N. The Formation of Impossible Rings in Macrocyclooligomerizations for Cyclodepsipeptide Synthesis: The 18-from-12 Paradox, The Journal of Organic Chemistry 2021, 86, 7904-7919.
} 
Benzyl (R)-2-(((6S,9R,12S)-2,2,5,6,11,12-hexamethyl-4,7,10-trioxo-9-pentyl-3,8-dioxa-5,11-

diazatridecan-13-oyl)oxy)heptanoate (ent-S2). Prepared following an identical procedure as S2. Flash column chromatography $\left(\mathrm{SiO}_{2}, 10-40 \%\right.$ ethyl acetate in hexanes) afforded the depsipeptide. All spectral data are in agreement with literature values. ${ }^{3}$

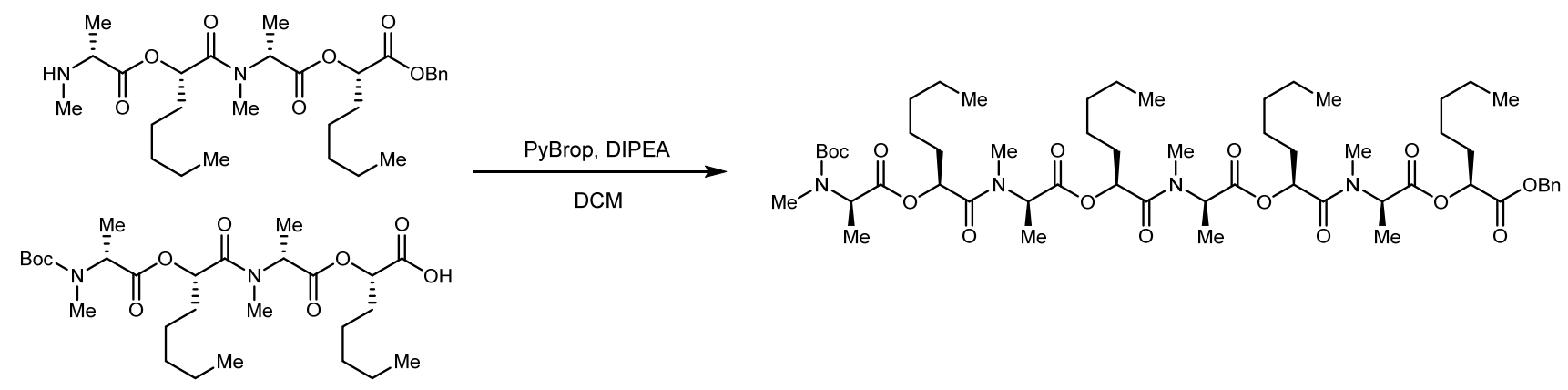

Benzyl (S)-2-(((6R,9S,12R,15S,18R,21S,24R)-2,2,5,6,11,12,17,18,23,24-decamethyl-4,7,10,13,16,19,22heptaoxo-9,15,21-tripentyl-3,8,14,20-tetraoxa-5,11,17,23-tetraazapentacosan-25-oyl)oxy)heptanoate (S3). A round-bottom flask was charged with the amine (195 mg, $365 \mu \mathrm{mol})$, acid (199 mg, $365 \mu \mathrm{mol})$, and DCM (3.7 mL). The mixture was cooled to $0{ }^{\circ} \mathrm{C}$ and then DIPEA (187 $\left.\mu \mathrm{L}, 1.09 \mathrm{mmol}\right)$ and PyBrop (255 $\mathrm{mg}, 547 \mu \mathrm{mol})$ were added. The reaction was stirred at $0{ }^{\circ} \mathrm{C}$ for $30 \mathrm{~min}$, then allowed to warm to ambient temperature and stir for an additional $1.5 \mathrm{~h}$. The reaction mixture was poured into cold $10 \%$ aq citric acid and extracted with DCM. The combined organic layers were washed with $\mathrm{NaHCO}_{3}$ and brine, and then dried, filtered, and concentrated. The crude residue was subjected to flash column chromatography $\left(\mathrm{SiO}_{2}, 10-50 \%\right.$ ethyl acetate in hexanes) to afford the product as a colorless oil (320 mg, 83\%). All spectral data are in agreement with literature values ${ }^{3}$ reported for the enantiomer, except $[\alpha]_{D}^{26}+42\left(c 0.94, \mathrm{CHCl}_{3}\right)$.

Benzyl (R)-2-(((6S,9R,12S,15R,18S,21R,24S)-2,2,5,6,11,12,17,18,23,24-decamethyl-4,7,10,13,16,19,22heptaoxo-9,15,21-tripentyl-3,8,14,20-tetraoxa-5,11,17,23-tetraazapentacosan-25-oyl)oxy)heptanoate (ent-S3). Prepared following an identical procedure as $\mathbf{S 3}$. Flash column chromatography $\left(\mathrm{SiO}_{2}, 10-50 \%\right.$ ethyl acetate in hexanes) afforded the depsipeptide. All spectral data are in agreement with literature values. $^{3}$ 


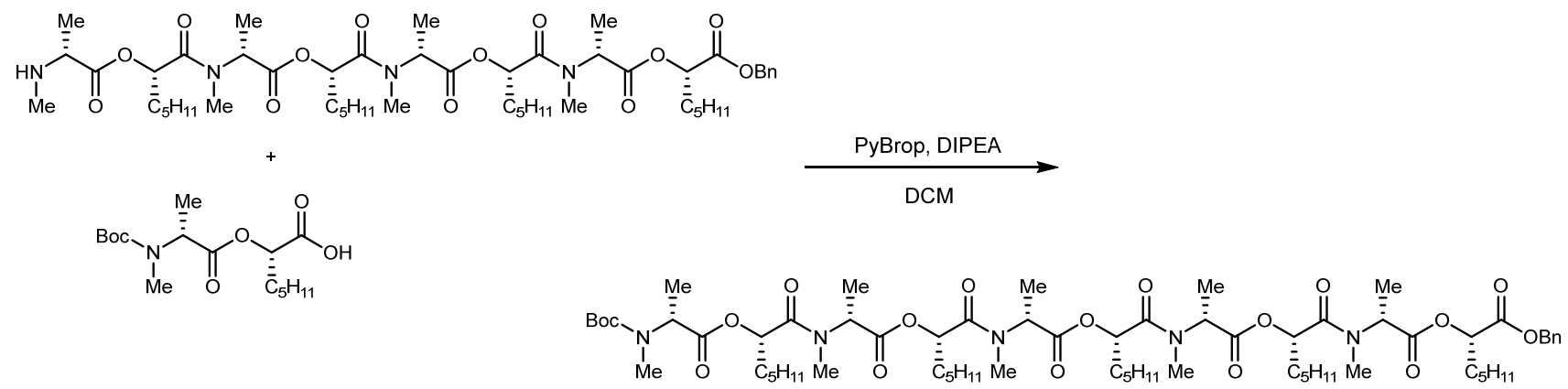

Benzyl (S)-2-(((6R,9S,12R,15S,18R,21S,24R,27S,30R)-2,2,5,6,11,12,17,18,23,24,29,30-dodecamethyl4,7,10,13,16,19,22,25,28-nonaoxo-9,15,21,27-tetrapentyl-3,8,14,20,26-pentaoxa-5,11,17,23,29pentaazahentriacontan-31-oyl)oxy)heptanoate (S4). A round-bottom flask was charged with the amine (45.0 mg, $47.1 \mu \mathrm{mol})$, acid (16.0 mg, $47.1 \mu \mathrm{mol})$, and $\mathrm{DCM}(0.5 \mathrm{~mL})$. The mixture was cooled to $0{ }^{\circ} \mathrm{C}$ and then DIPEA ( $24 \mu \mathrm{L}, 71 \mu \mathrm{mol})$ and PyBrop $(33.0 \mathrm{mg}, 70.7 \mu \mathrm{mol})$ were added. The reaction was stirred at 0 ${ }^{\circ} \mathrm{C}$ for $30 \mathrm{~min}$, then allowed to warm to ambient temperature and stir for an additional $1.5 \mathrm{~h}$. The reaction mixture was poured into cold $10 \%$ aq citric acid and extracted with DCM. The combined organic layers were washed with $\mathrm{NaHCO}_{3}$ and brine, and then dried, filtered, and concentrated. The crude residue was subjected to flash column chromatography $\left(\mathrm{SiO}_{2}, 10-60 \%\right.$ ethyl acetate in hexanes) to afford the product as a colorless oil (50 mg, 83\%). $[\alpha]_{D}^{25}+47.4$ (c 1.00, $\left.\mathrm{CHCl}_{3}\right) ; \mathrm{R}_{f}=0.21$ (40\% EtOAc/hexanes); IR (film) 2933, 2865, 1742, 1664, 1459, 1315, 1213, $1085 \mathrm{~cm}^{-1}$; ${ }^{1} \mathrm{H}$ NMR (600 MHz, CDCl 3 ) This compound exists as a mixture of rotamers causing significant peak broadening and overlap. Refer to the image of the ${ }^{1} \mathrm{H}$ NMR spectrum; ${ }^{13} \mathrm{C} \mathrm{NMR}\left(150 \mathrm{MHz}, \mathrm{CDCl}_{3}\right)$ This compound is a mixture of rotamers causing significant peak broadening and overlap. Refer to the image of the ${ }^{13} \mathrm{C}$ NMR spectrum; HRMS (EI): Exact mass calcd for $\mathrm{C}_{67} \mathrm{H}_{115} \mathrm{~N}_{6} \mathrm{O}_{18}\left[\mathrm{M}+\mathrm{NH}_{4}\right]^{+} 1291.8262$, found 1291.8259 .

\section{Benzyl (R)-2-(((6S,9R,12S,15R,18S,21R,24S,27R,30S)-2,2,5,6,11,12,17,18,23,24,29,30-dodecamethyl-} 4,7,10,13,16,19,22,25,28-nonaoxo-9,15,21,27-tetrapentyl-3,8,14,20,26-pentaoxa-5,11,17,23,29pentaazahentriacontan-31-oyl)oxy)heptanoate (ent-S4). Prepared following an identical procedure as S4. Flash column chromatography $\left(\mathrm{SiO}_{2}, 10-60 \%\right.$ ethyl acetate in hexanes) afforded the protected depsipeptide with spectroscopic data identical to its enantiomer, except $[\alpha]_{D}^{22}-30$ (c 0.16, $\mathrm{CHCl}_{3}$ ). 

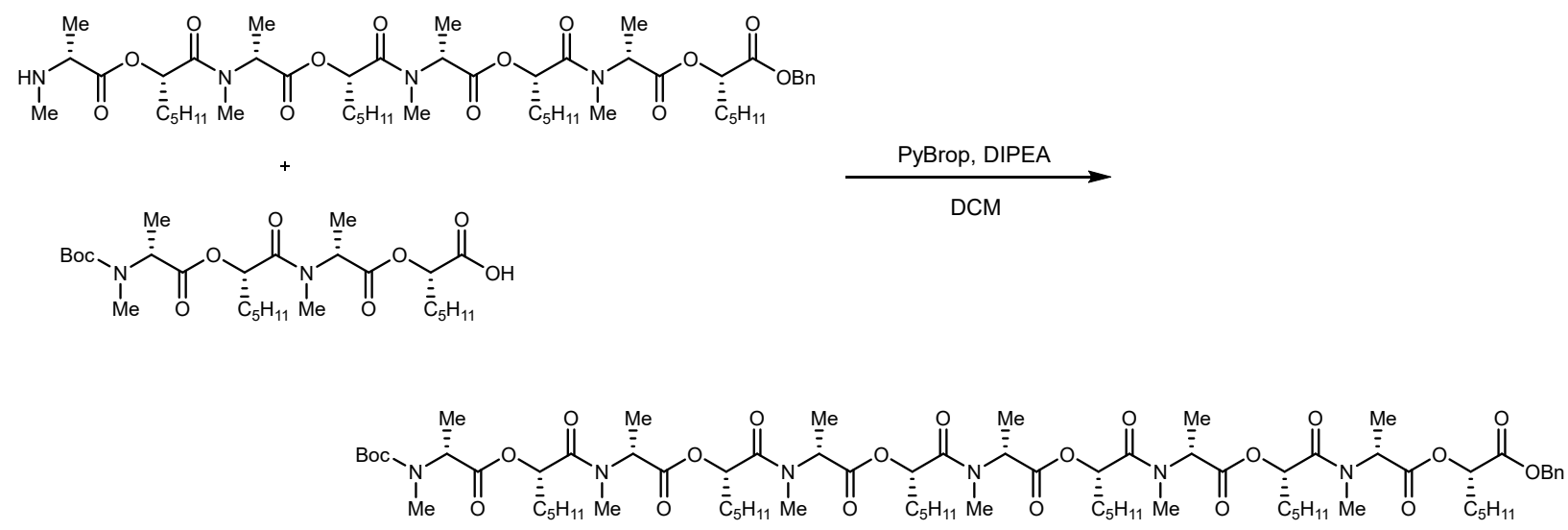

Benzyl (S)-2-(((6R,9S,12R,15S,18R,21S,24R,27S,30R,33S,36R)-2,2,5,6,11,12,17,18,23,24,29,30,35,36tetradecamethyl-4,7,10,13,16,19,22,25,28,31,34-undecaoxo-9,15,21,27,33-pentapentyl-

3,8,14,20,26,32-hexaoxa-5,11,17,23,29,35-hexaazaheptatriacontan-37-oyl)oxy)heptanoate (S5). A round-bottom flask was charged with the amine $(45.0 \mathrm{mg}, 47.1 \mu \mathrm{mol})$, acid $(25.7 \mathrm{mg}, 47.1 \mu \mathrm{mol})$, and DCM $(0.5 \mathrm{~mL})$. The mixture was cooled to $0{ }^{\circ} \mathrm{C}$ and then DIPEA $(24 \mu \mathrm{L}, 71 \mu \mathrm{mol}$ ) and PyBrop $(33.0 \mathrm{mg}$, $70.7 \mathrm{\mu mol}$ ) were added. The reaction mixture was stirred at $0{ }^{\circ} \mathrm{C}$ for $30 \mathrm{~min}$, then allowed to warm to ambient temperature and stir for an additional $1.5 \mathrm{~h}$. The reaction mixture was poured into cold $10 \%$ aq citric acid and extracted with DCM. The combined organic layers were washed with $\mathrm{NaHCO}_{3}$ and brine, and dried, filtered, and concentrated. The crude residue was subjected to flash column chromatography $\left(\mathrm{SiO}_{2}, 10-60 \%\right.$ ethyl acetate in hexanes) to afford the product as a colorless oil (70 mg, 99\%). $[\alpha]_{D}^{20}+53$ ( $c$ 0.95, $\left.\mathrm{CHCl}_{3}\right) ; \mathrm{R}_{f}=0.15$ (50\% EtOAc/hexanes); IR (film) 2932, 2864, 1743, 1664, 1458, 1315, 1215, 1085 $\mathrm{cm}^{-1} ;{ }^{1} \mathrm{H}$ NMR $\left(600 \mathrm{MHz}, \mathrm{CDCl}_{3}\right)$ This compound exists as a mixture of rotamers causing significant peak broadening and overlap. Refer to image of the ${ }^{1} \mathrm{H}$ NMR spectrum; ${ }^{13} \mathrm{C} \mathrm{NMR}\left(150 \mathrm{MHz}, \mathrm{CDCl}_{3}\right)$ This compound is a mixture of rotamers causing significant peak broadening and overlap. Refer to the image of the ${ }^{13} \mathrm{C}$ NMR spectrum; HRMS (EI): Exact mass calcd for $\mathrm{C}_{78} \mathrm{H}_{134} \mathrm{~N}_{7} \mathrm{O}_{21}\left[\mathrm{M}+\mathrm{NH}_{4}\right]^{+} 1504.9627$, found 1504.9620.

Benzyl (R)-2-(((6S,9R,12S,15R,18S,21R,24S,27R,30S,33R,36S)-2,2,5,6,11,12,17,18,23,24,29,30,35,36tetradecamethyl-4,7,10,13,16,19,22,25,28,31,34-undecaoxo-9,15,21,27,33-pentapentyl3,8,14,20,26,32-hexaoxa-5,11,17,23,29,35-hexaazaheptatriacontan-37-oyl)oxy)heptanoate (ent-S5). Prepared following an identical procedure as S5. Flash column chromatography $\left(\mathrm{SiO}_{2}, 10-60 \%\right.$ ethyl acetate in hexanes) afforded the depsipeptide with spectroscopic data identical to its enantiomer, except $[\alpha]_{D}^{20}-42\left(c 0.15, \mathrm{CHCl}_{3}\right)$. 


\section{Biological Experiments}

All experiments were approved by the Animal Care and Use Committee of Vanderbilt University.

Experiments were conducted in cardiomyocytes isolated from CASQ2 gene knockout mice and carried out as described in Batiste et al. ${ }^{5}$ Dose-response curves were fit using the equation $Y=B o t t o m+(T o p-$ Bottom $) /\left(1+10^{\wedge}(X-L o g I C 50)\right)$ in GraphPad Prism. Statistical significance was calculated in GraphPad Prism using a one-way ANOVA followed by Tukey's post-hoc test and using an adjusted p-value of 0.05 as the threshold for significance.

\footnotetext{
${ }^{5}$ Batiste, S. M.; Blackwell, D. J.; Kim, K.; Kryshtal, D. O.; Gomez-Hurtado, N.; Rebbeck, R. T.; Cornea, R. L.; Johnston, J. N.; Knollmann, B. C. Unnatural verticilide enantiomer inhibits type 2 ryanodine receptor-mediated calcium leak and is antiarrhythmic, Proceedings of the National Academy of Sciences 2019, 116, 4810-4815.
} 
Figure S1. ${ }^{1} \mathrm{H}$ NMR $\left(400 \mathrm{MHz}, \mathrm{CDCl}_{3}\right)$ of 3

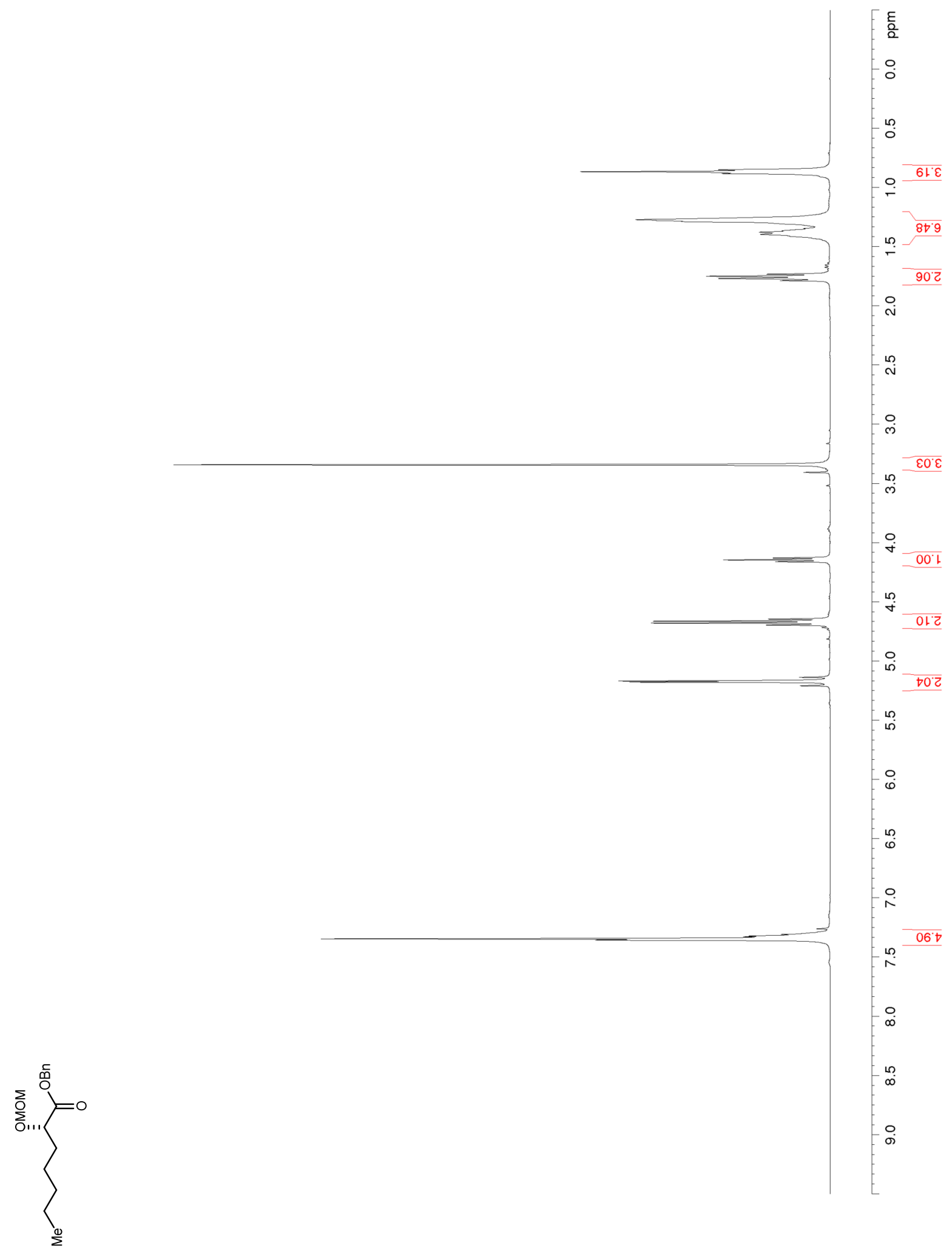


Figure $\mathrm{S} 2 .{ }^{13} \mathrm{C}$ NMR/DEPT (100 MHz, $\left.\mathrm{CDCl}_{3}\right)$ of 3
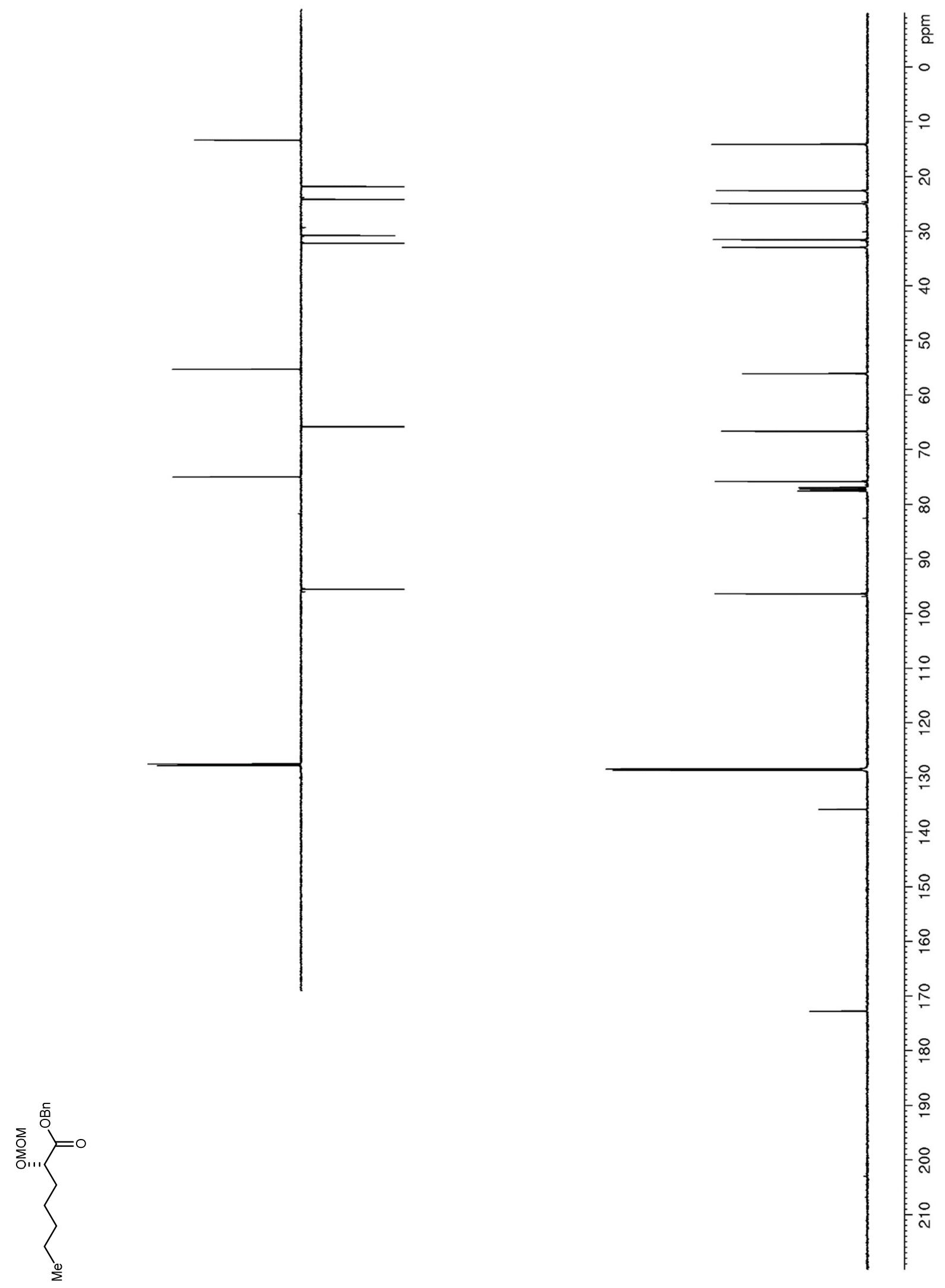
Figure S3. ${ }^{1} \mathrm{H} \mathrm{NMR}\left(600 \mathrm{MHz}, \mathrm{CDCl}_{3}\right)$ of 6

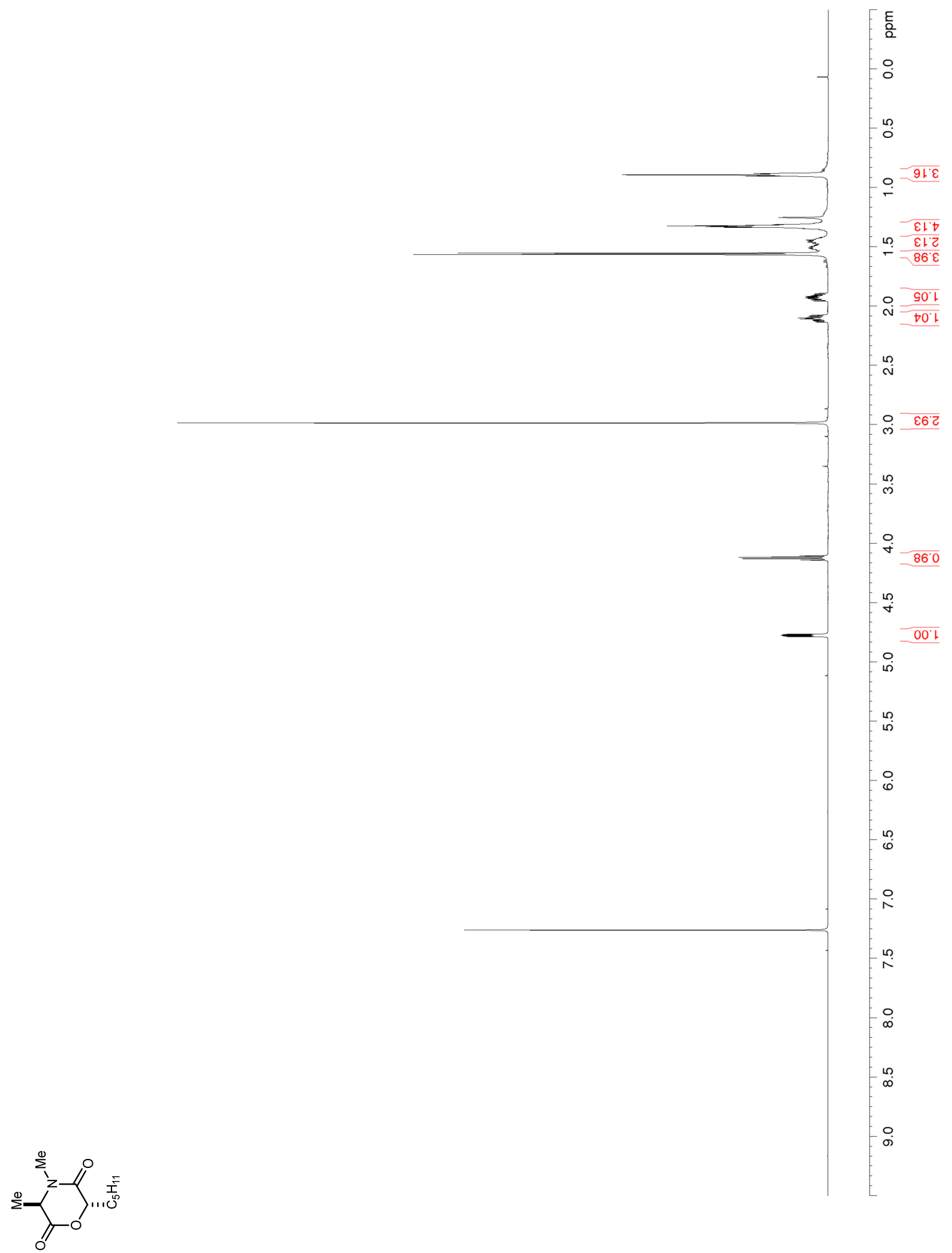


Figure $\mathrm{S} 4 .{ }^{13} \mathrm{C}$ NMR/DEPT (125 MHz, $\left.\mathrm{CDCl}_{3}\right)$ of 6

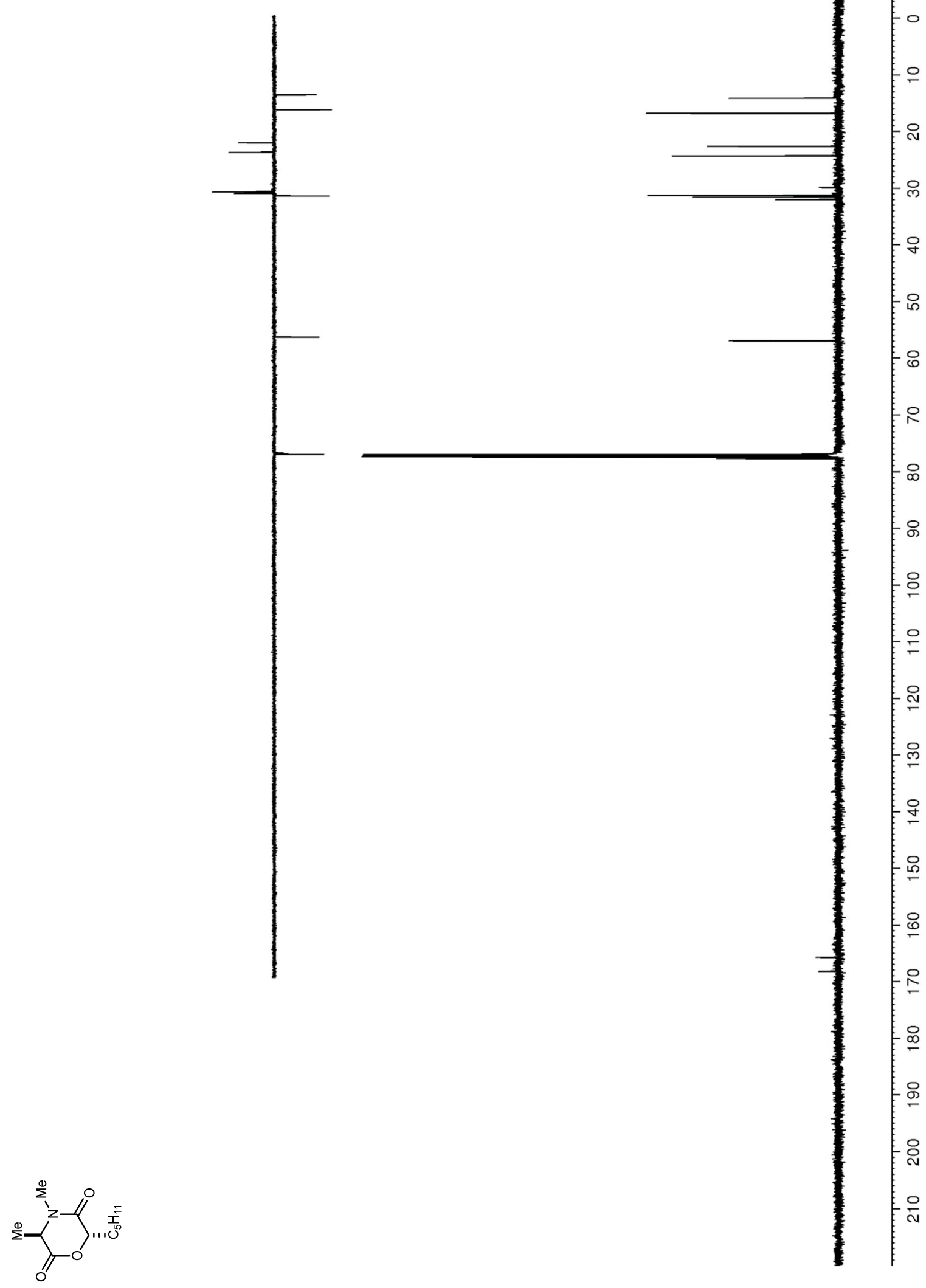


Figure $\mathrm{S} 5 .{ }^{1} \mathrm{H} \mathrm{NMR}\left(600 \mathrm{MHz}, \mathrm{CDCl}_{3}\right)$ of 7

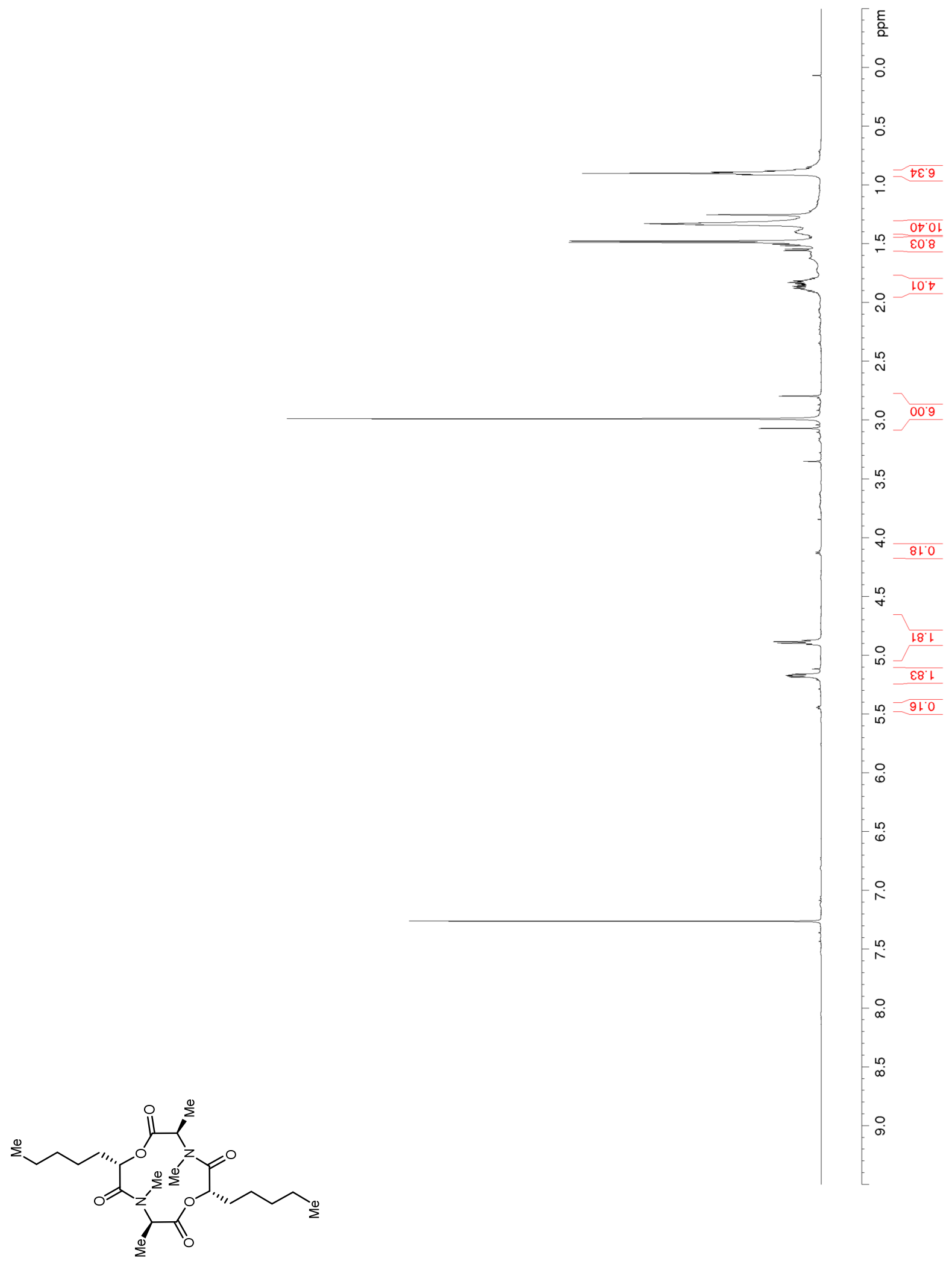


Figure S6. ${ }^{13} \mathrm{C}$ NMR/DEPT (125 MHz, CDCl $)$ of 7

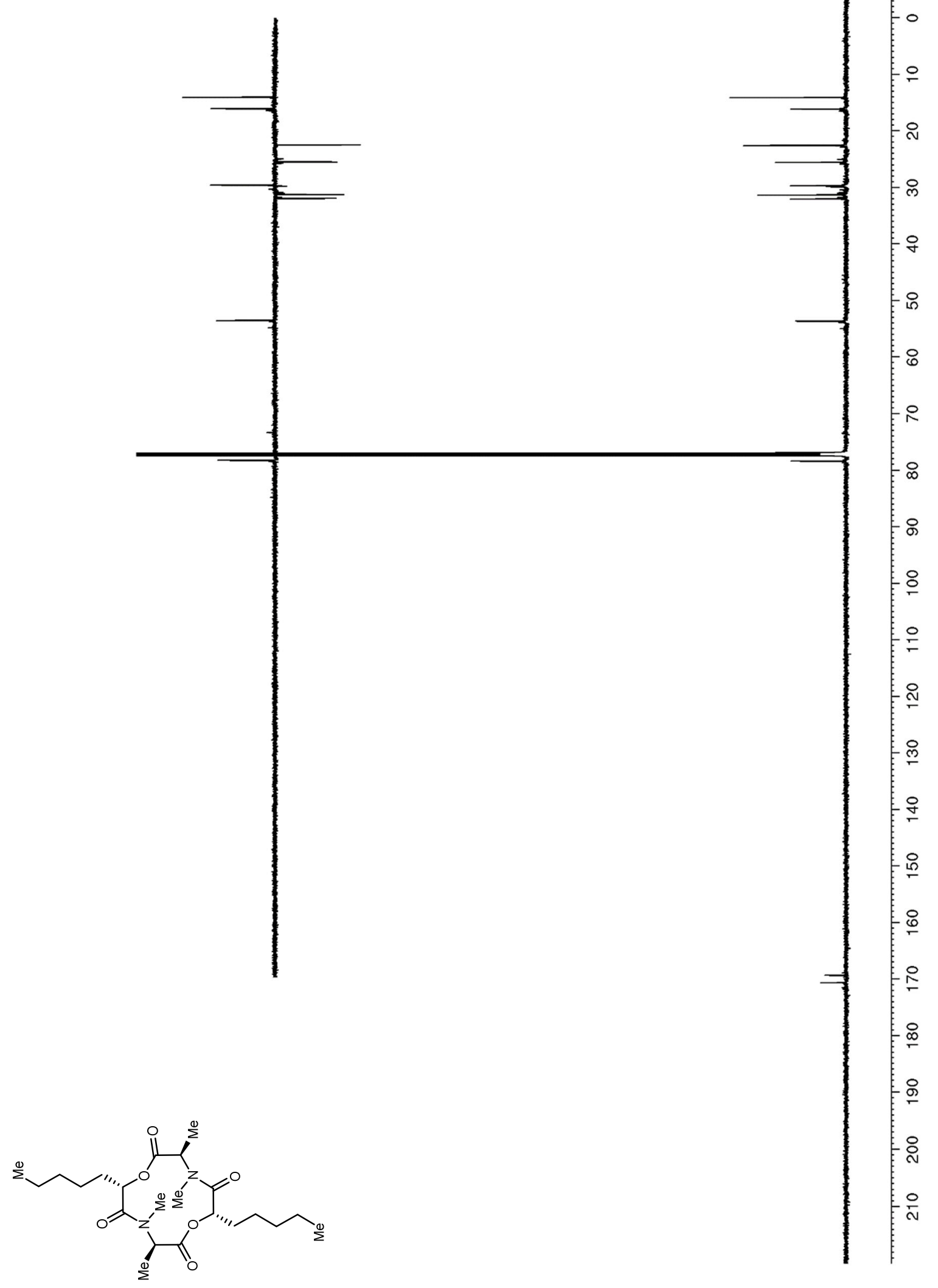


Figure S7. ${ }^{1} \mathrm{H} N M R\left(600 \mathrm{MHz}, \mathrm{CD}_{3} \mathrm{OD}\right)$ of 8

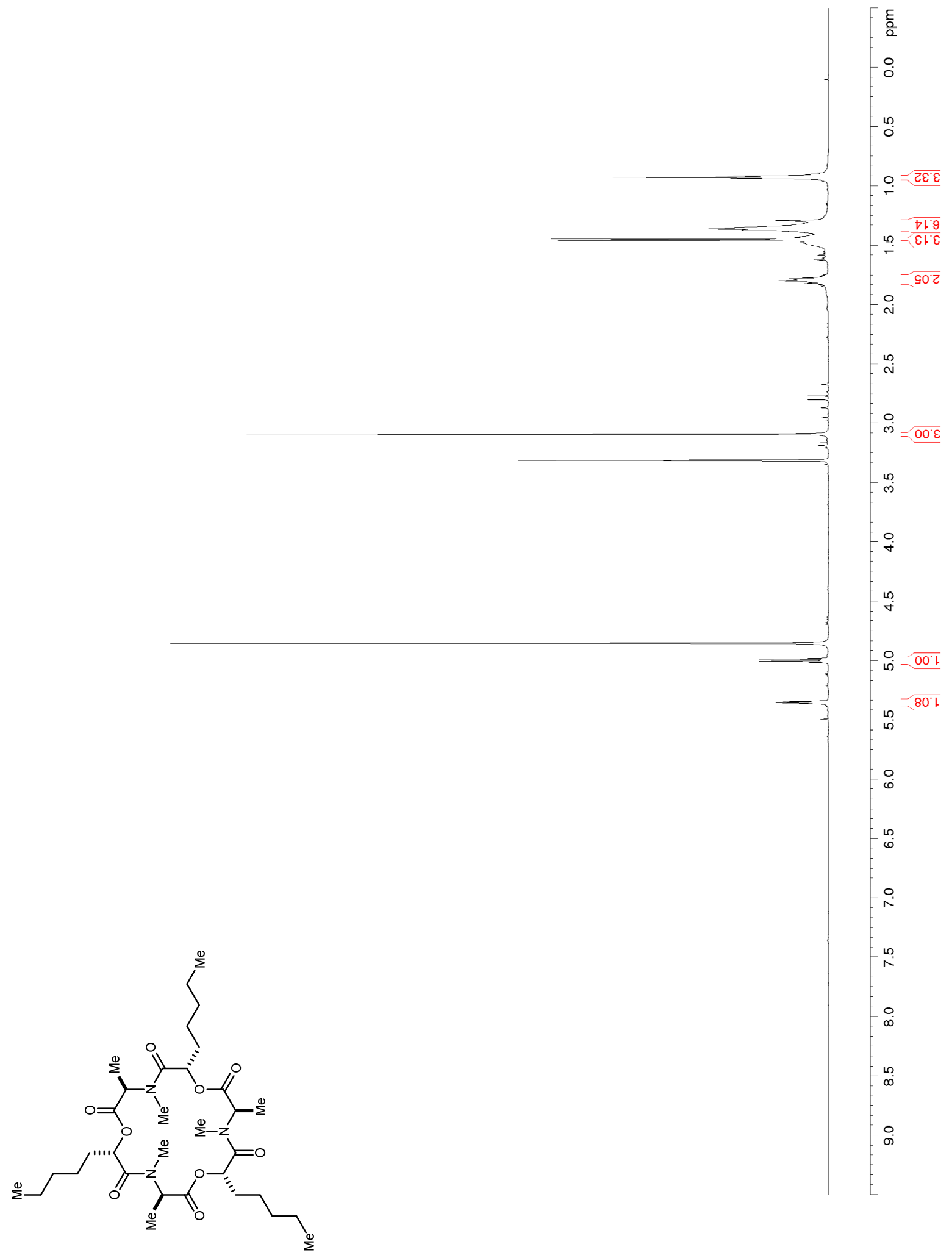


Figure S8. ${ }^{13} \mathrm{C}$ NMR/DEPT (150 MHz, CD 3 OD) of 8

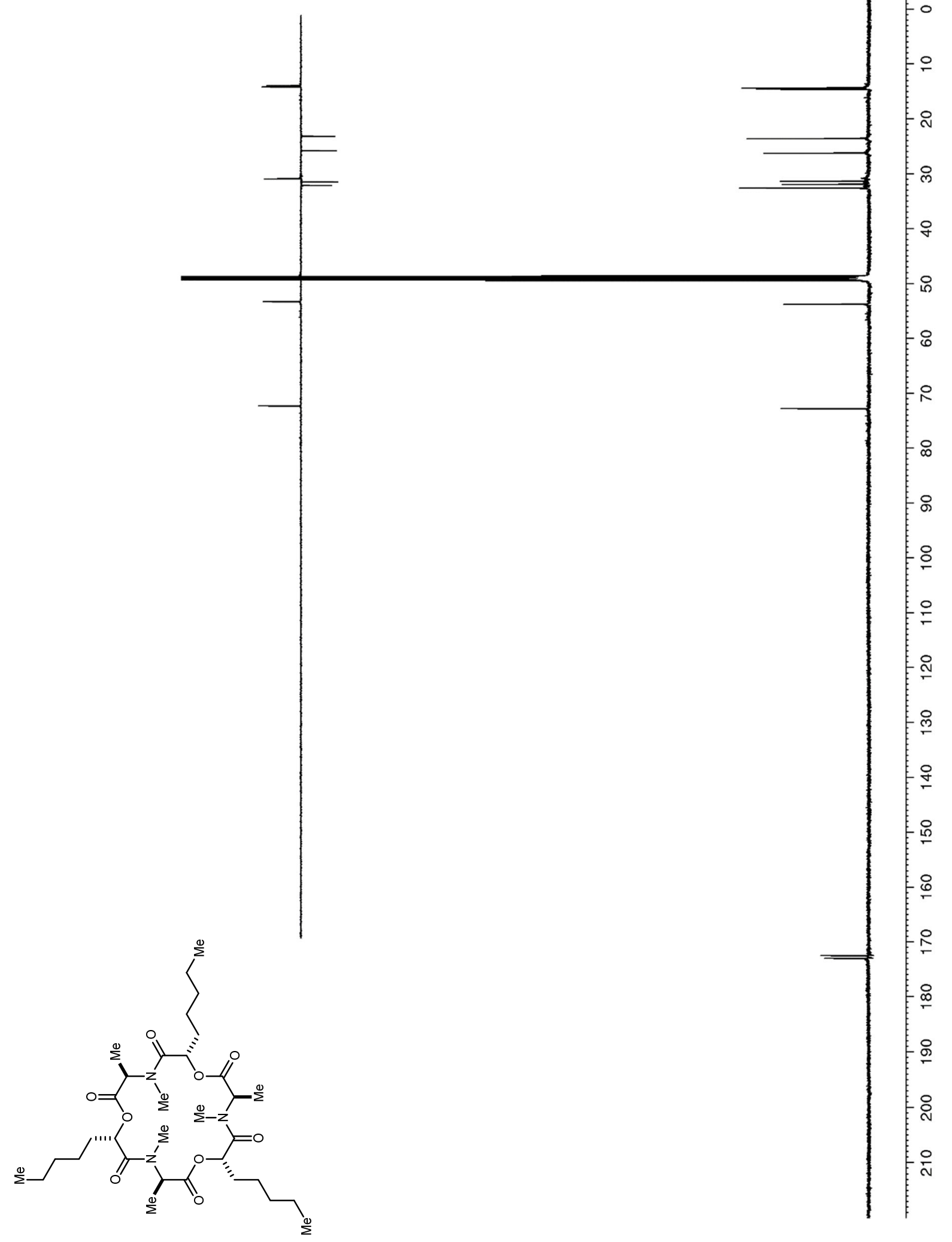


Figure S9. ${ }^{1} \mathrm{H} \mathrm{NMR}\left(600 \mathrm{MHz}, \mathrm{CDCl}_{3}\right)$ of 10

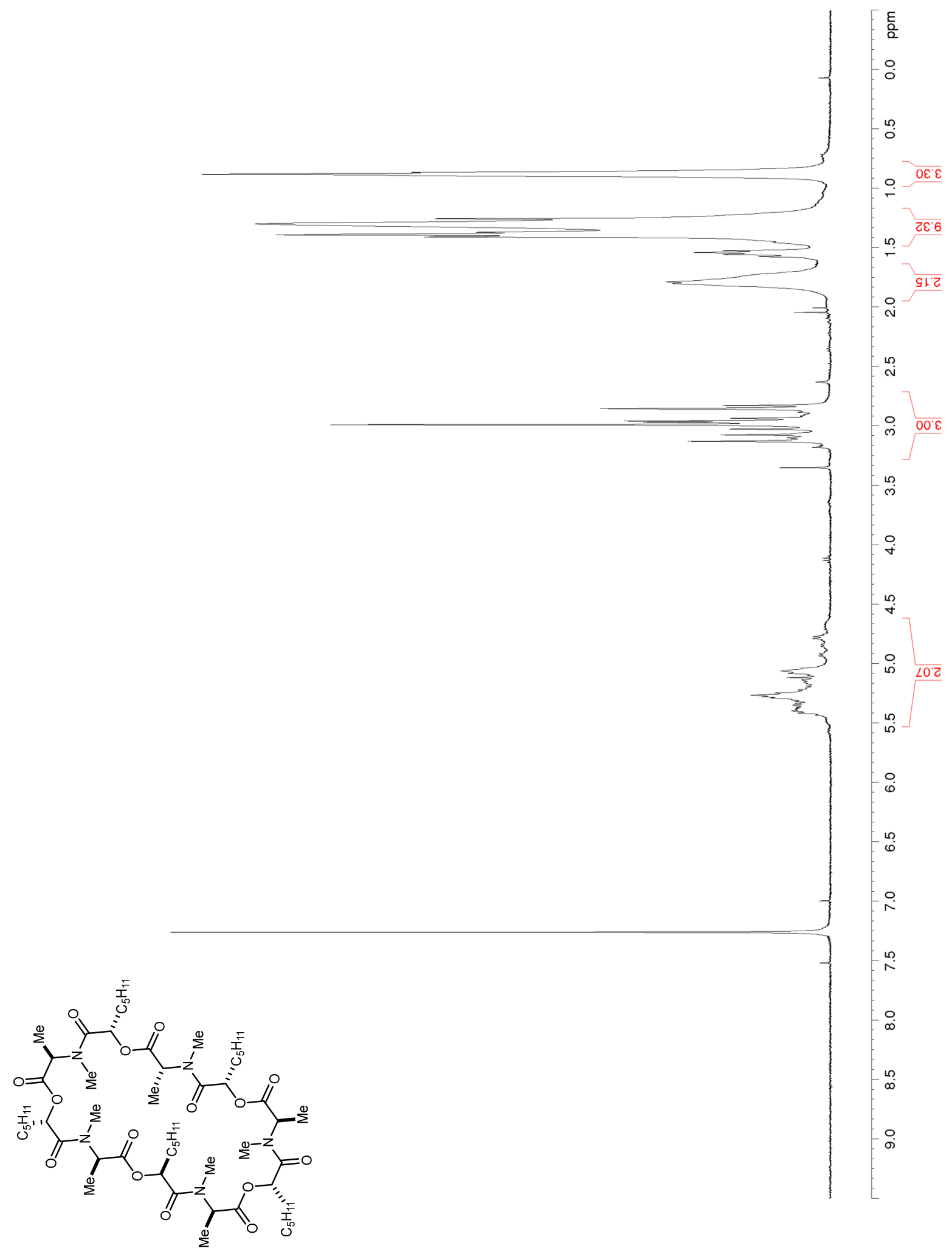


Figure S10. ${ }^{13} \mathrm{C}$ NMR/DEPT (150 MHz, $\left.\mathrm{CDCl}_{3}\right)$ of 10

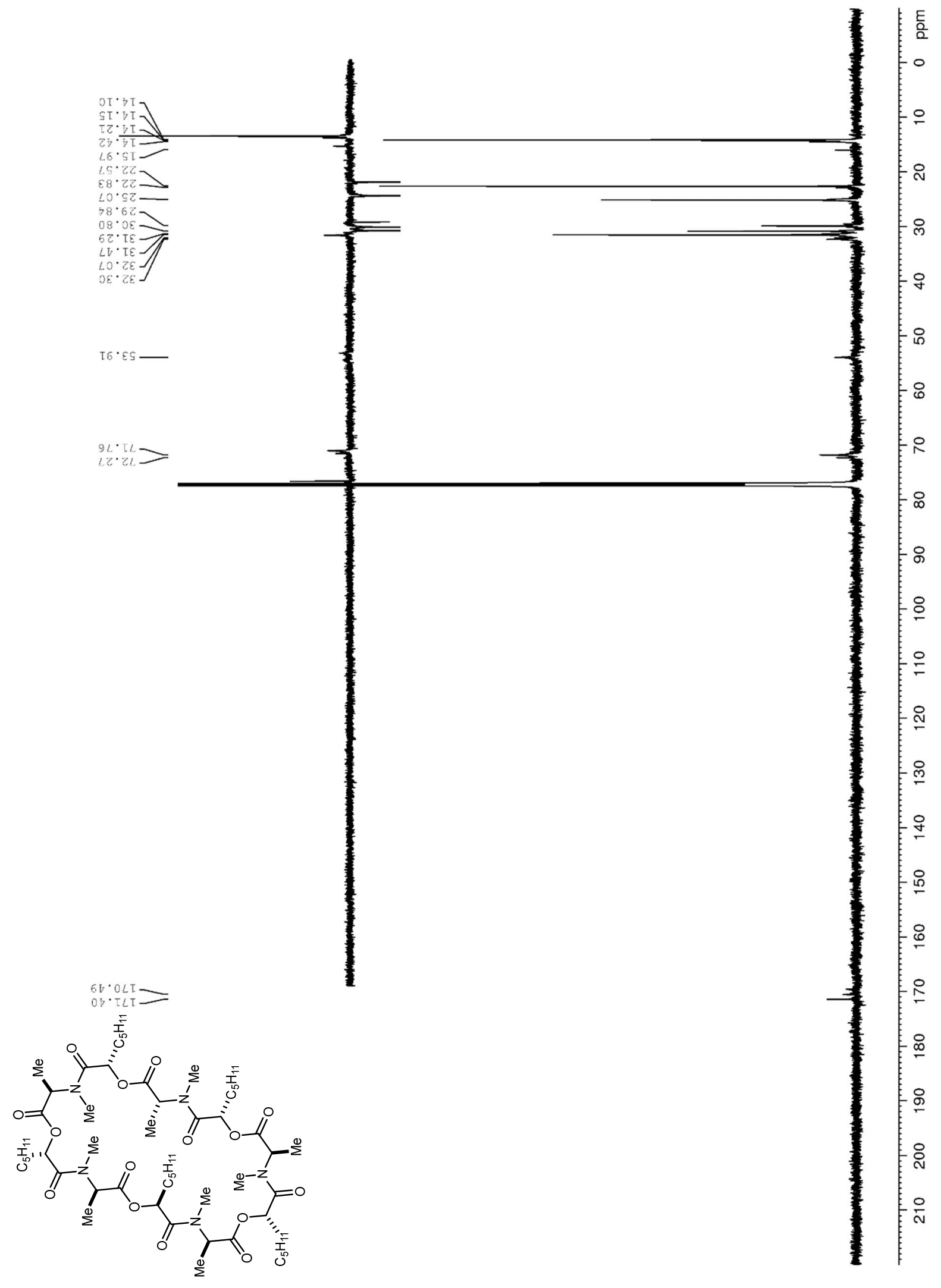


Figure S11. ${ }^{1} \mathrm{H} \mathrm{NMR}\left(600 \mathrm{MHz}, \mathrm{CDCl}_{3}\right)$ of 11

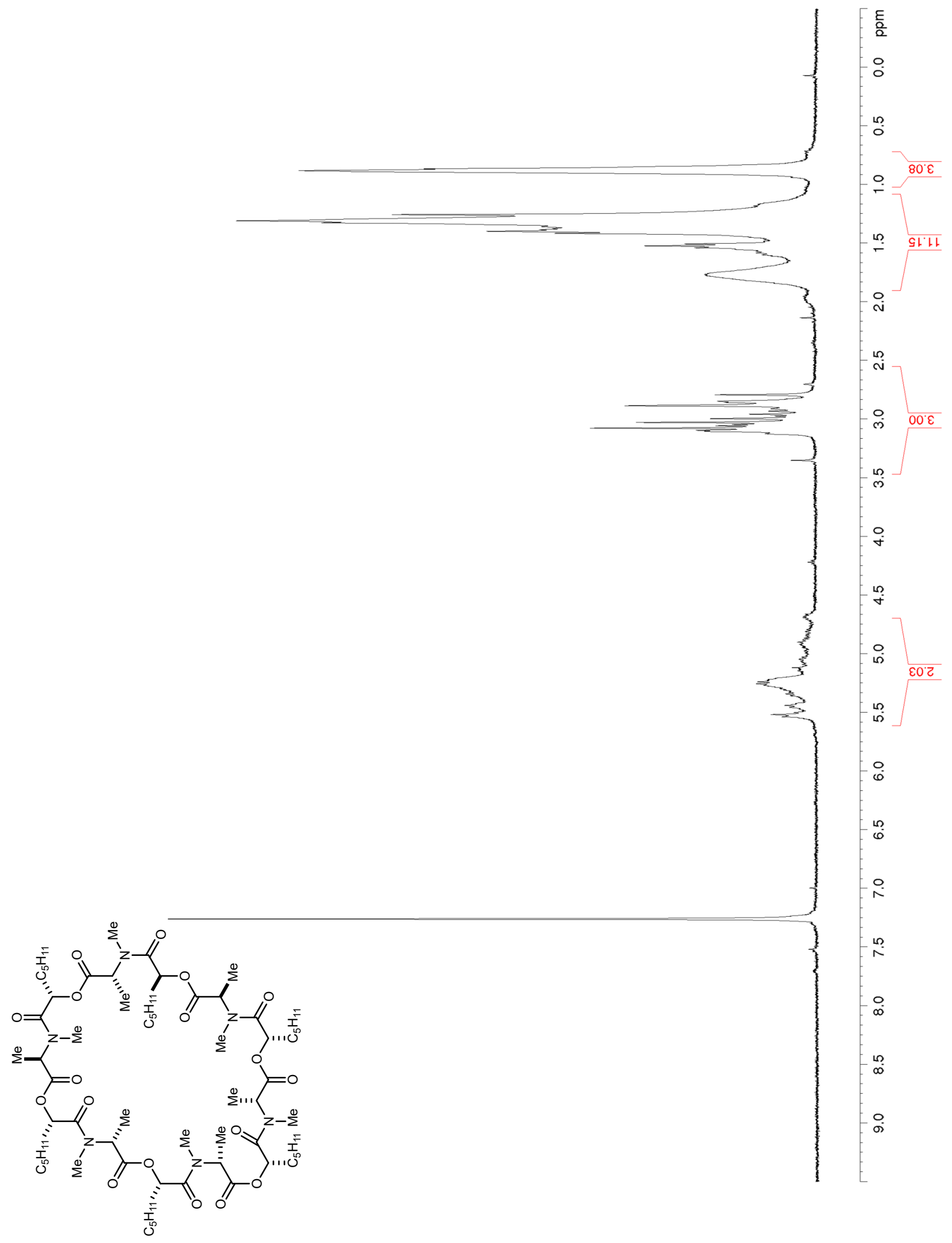


Figure S12. ${ }^{13} \mathrm{C}$ NMR/DEPT (150 MHz, $\left.\mathrm{CDCl}_{3}\right)$ of 11

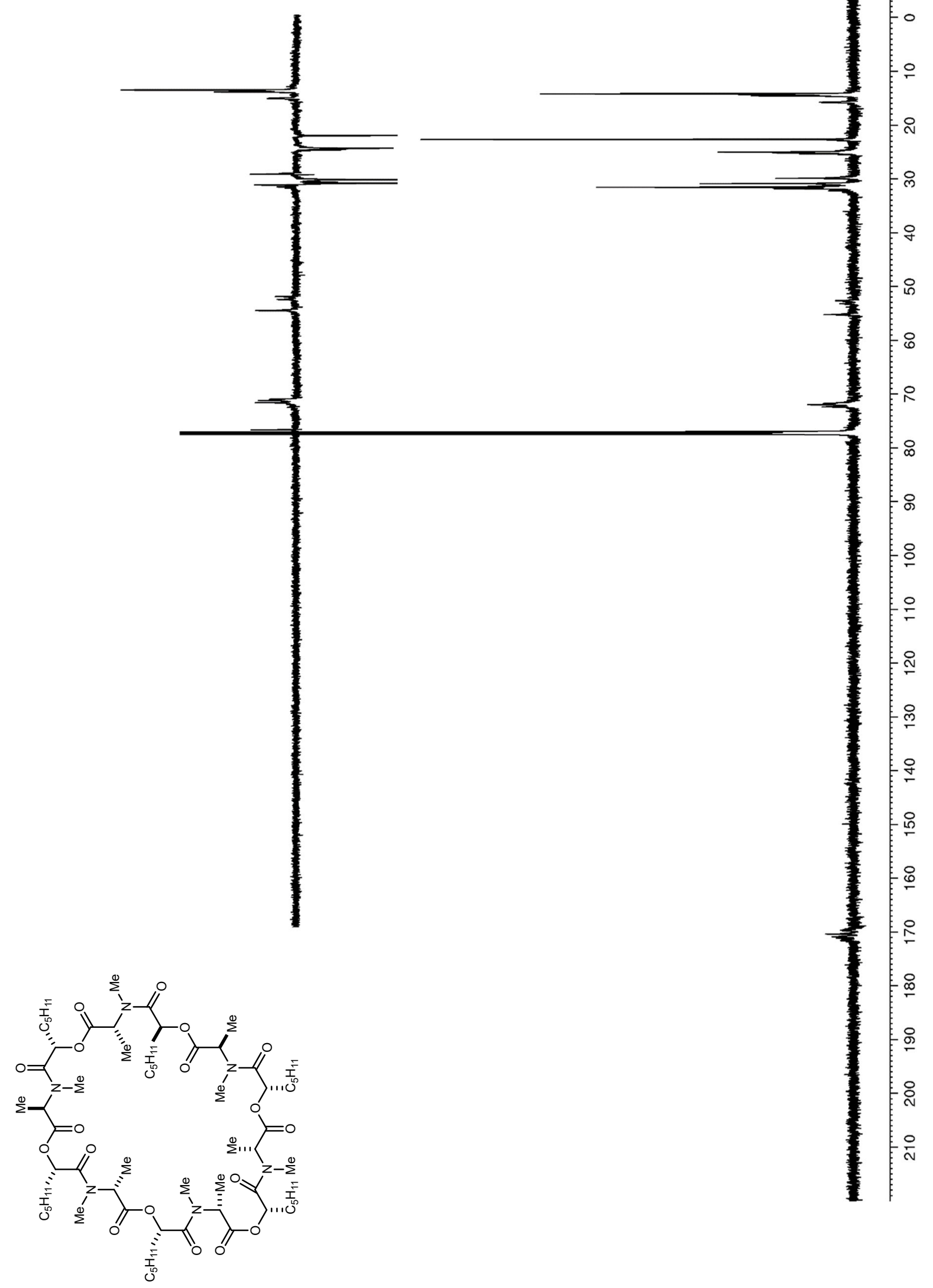


Figure $\mathrm{S} 13 .{ }^{1} \mathrm{H} \mathrm{NMR}\left(600 \mathrm{MHz}, \mathrm{CDCl}_{3}\right)$ of $\mathrm{S} 4$
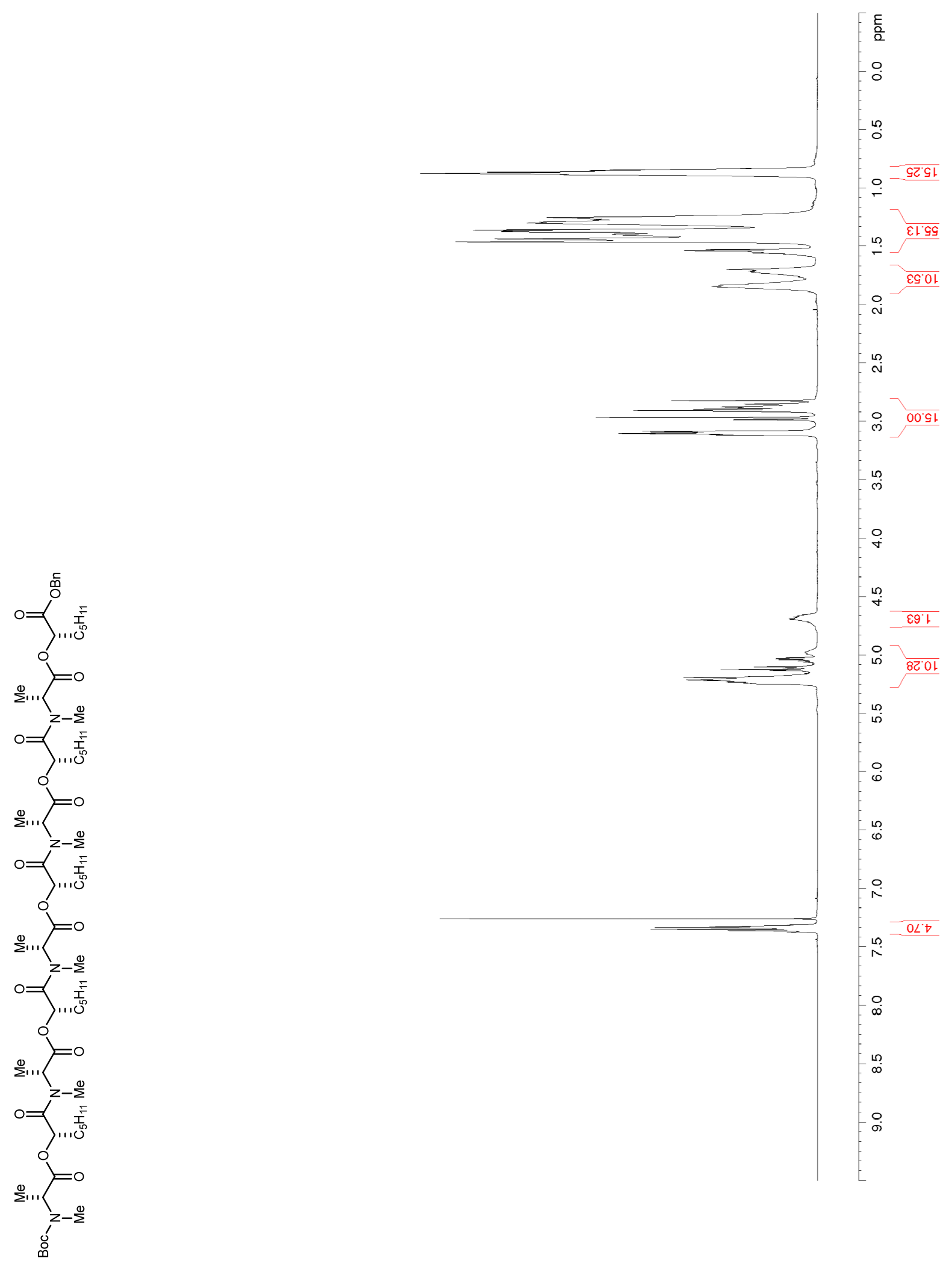
Figure $\mathrm{S} 14 .{ }^{13} \mathrm{C}$ NMR/DEPT $\left(150 \mathrm{MHz}, \mathrm{CDCl}_{3}\right)$ of $\mathrm{S} 4$

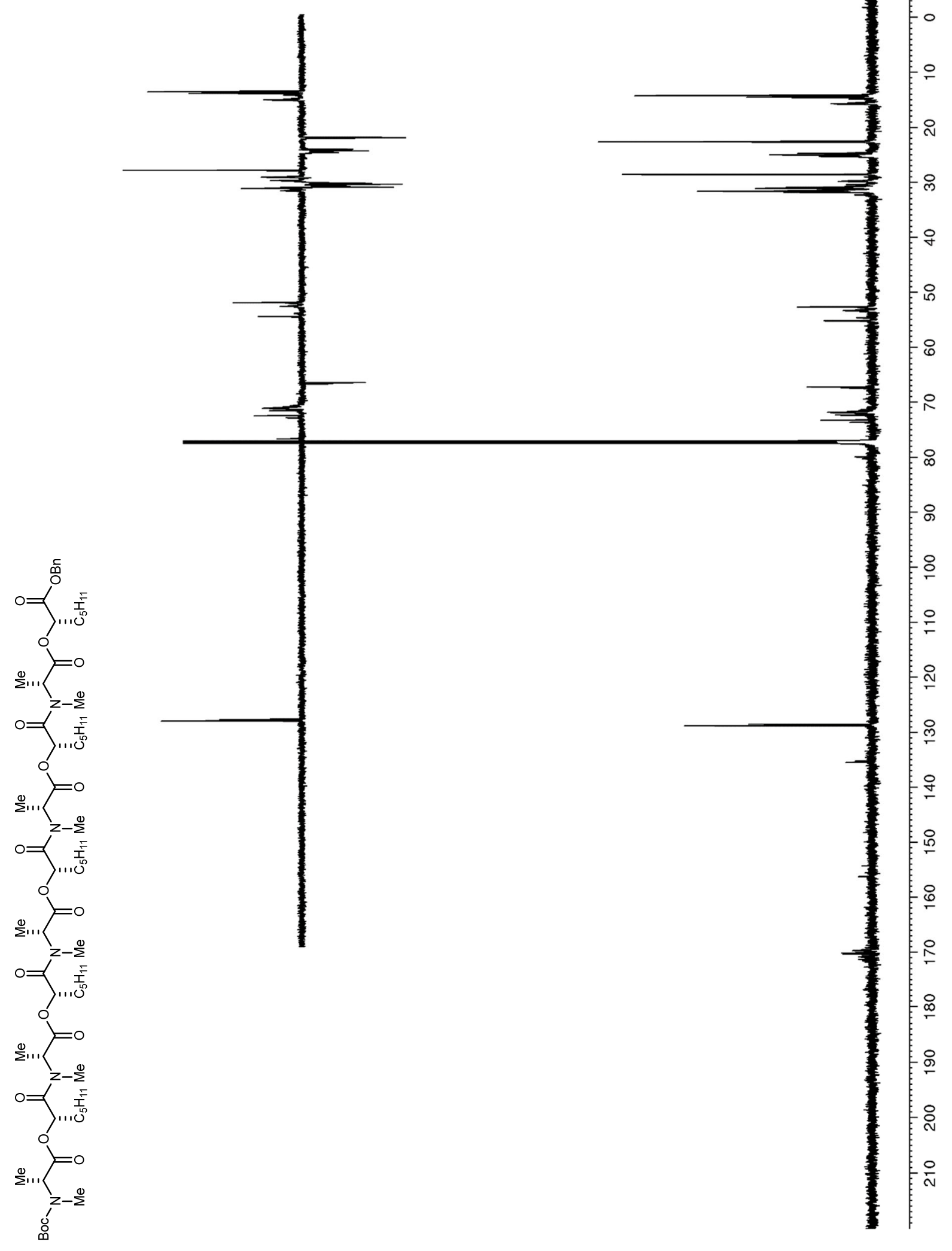


Figure $\mathrm{S} 15 .{ }^{1} \mathrm{H} \mathrm{NMR}\left(600 \mathrm{MHz}, \mathrm{CDCl}_{3}\right)$ of $\mathrm{S} 5$
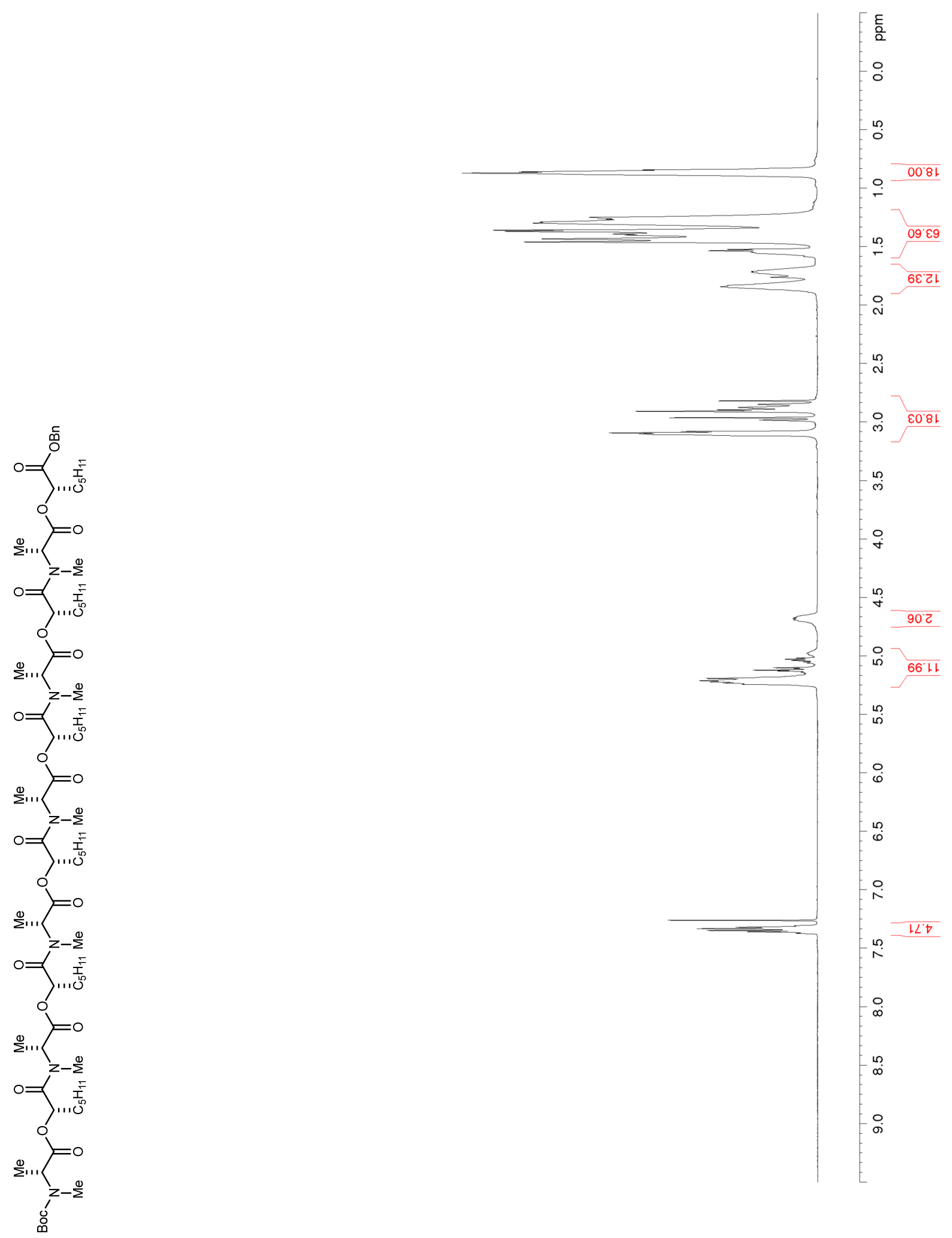
Figure S16. ${ }^{13} \mathrm{C} \mathrm{NMR/DEPT}\left(150 \mathrm{MHz}, \mathrm{CDCl}_{3}\right)$ of $\mathrm{S} 5$

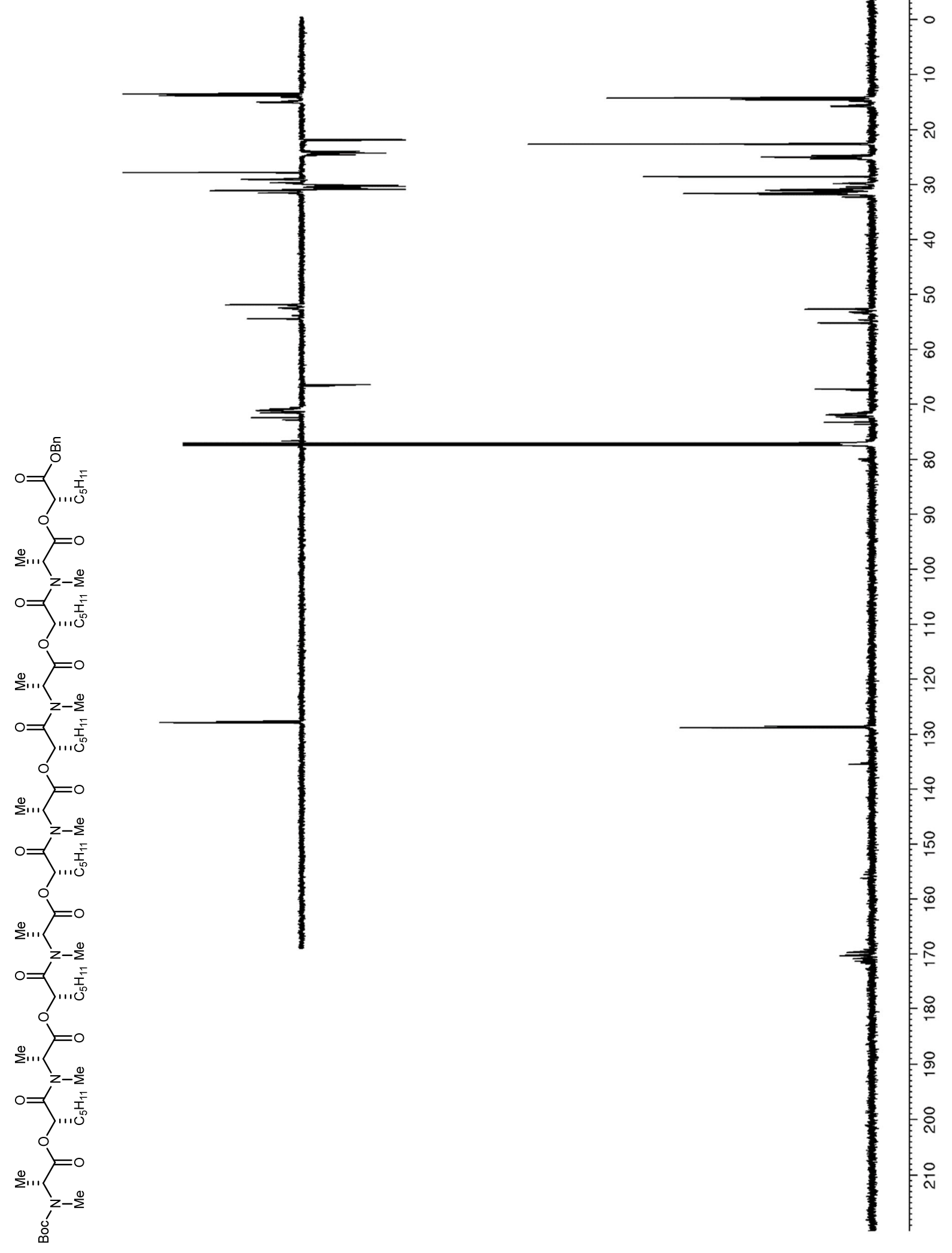

